\title{
The neuroinflammatory hypothesis of delirium
}

\author{
Joaquim Cerejeira $\cdot$ Horácio Firmino $\cdot$ \\ Adriano Vaz-Serra $\cdot$ Elizabeta B. Mukaetova-Ladinska
}

Received: 10 November 2009/Revised: 8 March 2010/Accepted: 13 March 2010

(C) Springer-Verlag 2010

\begin{abstract}
Delirium is a neuropsychiatric syndrome characterized by a sudden and global impairment in consciousness, attention and cognition. It is particularly frequent in elderly subjects with medical or surgical conditions and is associated with short- and long-term adverse outcomes. The pathophysiology of delirium remains poorly understood as it involves complex multi-factorial dynamic interactions between a diversity of risk factors. Several conditions associated with delirium are characterized by activation of the inflammatory cascade with acute release of inflammatory mediators into the bloodstream. There is compelling evidence that acute peripheral inflammatory stimulation induces activation of brain parenchymal cells, expression of proinflammatory cytokines and inflammatory mediators in the central nervous system. These neuroinflammatory changes induce neuronal and synaptic dysfunction and subsequent neurobehavioural and cognitive symptoms. Furthermore, ageing and neurodegenerative disorders exaggerate microglial responses following stimulation by systemic immune stimuli such as peripheral inflammation and/or infection. In this review we explore the
\end{abstract}

J. Cerejeira · A. Vaz-Serra

Coimbra University, Coimbra, Portugal

J. Cerejeira $(\bowtie) \cdot$ H. Firmino · A. Vaz-Serra

Serviço de Psiquiatria, Hospitais da Universidade de Coimbra,

3000 Coimbra, Portugal

e-mail: jcerejeira@netcabo.pt

E. B. Mukaetova-Ladinska

Institute for Ageing and Health, Newcastle University,

Newcastle upon Tyne NE5 5PL, UK neuroinflammatory hypothesis of delirium based on recent evidence derived from animal and human studies.

\section{Introduction}

Delirium is a common neuropsychiatric syndrome clinically characterized by a sudden onset and transient impairment of consciousness and attention, with consecutive global disturbance in cognition and behaviour. It affects predominantly elderly subjects, with reported rates depending on the sample and setting considered, being associated with both short- and long-term adverse outcomes [94]. Thus, in medical in-patient settings, the occurrence rate per admission is $11-42 \%$ [125]. In elective orthopaedic surgery the incidence of postsurgical delirium ranges from 9 to $28 \%$ [145]. Higher rates are seen in emergent hip fracture surgery in which a large proportion of patients present with preoperative (4-36\%) or post-operative delirium (up to 53\%) [19]. Post-operative delirium after cardiac surgery varies from 2 to $57 \%$ according to the procedure, type of patients and study methodology $[22,138]$. In the context of sepsis, delirium affects $9-71 \%$ of patients [37].

As with other neuropsychiatric disorders, the pathophysiology of delirium remains poorly understood for a number of reasons. First, the core features of delirium (impaired level of consciousness and inattention) are difficult to define and to operationalize. Secondly, the protean nature of delirium with respect to clinical symptoms, severity and evolution challenges its recognition. Thirdly, delirium has significant aetiological complexity reflecting the dynamic interaction of multiple environmental and individual factors. Finally, the inaccessibility of the central nervous system (CNS) limits the exploration of the neurobiological correlates of the high integrative cognitive 
functions globally affected during delirium. Not surprisingly, despite its clinical relevance, delirium has been a relatively neglected area of research. However, considering that delirium is a syndrome in which the link between brain and body is most clear, ongoing advances in the understanding of the interaction between the CNS and peripheral organs through bloodstream herald important breakthroughs in the study of its pathophysiology.

In this study we explore the contribution of the neuroinflammatory pathway to delirium. First, evidence associating systemic inflammation with delirium is presented. Then, we review the sequence of events explaining the relation between acute systemic inflammatory stimulation and delirium. Given the absence of neuropathological studies in humans during the acute phase of delirium, animal models provide the best available opportunity to study the neurobiological correlates of acute cognitive and behavioural dysfunction following systemic inflammation. Whenever possible, evidence obtained from human studies is discussed. Studies evaluating the effect of the ageing process and neurodegeneration are also analysed in order to elucidate how these two known major risk factors for delirium are involved in its pathophysiology. Finally, we present some future perspectives on how these concepts can be useful to develop new therapeutic measures to prevent delirium. Taken together, these data provide a framework with heuristic value to guide new approaches in the study of delirium.

\section{Delirium concept}

\section{Clinical definition of delirium}

Following the landmark work of Engel and Romano [42], delirium has been conceptualized as a reversible state of cerebral insufficiency comparable to the more familiar concepts of renal or hepatic insufficiency. Although this clinical syndrome was one of the first mental illnesses to be recognized, its nosologic classification remains a continually evolving process. This is reflected in the scientific literature by the use of a confusing plethora of terms referring to conditions that are embraced in the concept of delirium as defined in the Diagnostic and Statistical Manual of Mental Disorders (DSM-IV-TR) [5] or in the tenth edition of the International Statistical Classification of Diseases and Related Health Problems [146]. Often, different labels are used specifically in some settings to describe the condition at a clinical (e.g. acute confusional state) or pathophysiological level (e.g. encephalopathy and acute brain failure). This reveals both the multifaceted nature of delirium and the lack of a consistent approach to this syndrome.

Currently, delirium is defined in DSM-IV-TR [5] by the presence of disturbed consciousness (i.e. reduced clarity of awareness of the environment with reduced ability to focus, to sustain, or to shift attention) and a change in cognition (such as memory deficit, disorientation, or language disturbance) or the development of a perceptual disturbance that is not better accounted for by a pre-existing, established or evolving dementia. The disturbance develops over a short period of time (usually hours to days) and tends to fluctuate during the course of the day. There is evidence from clinical history, physical examination, and/or laboratory findings that the disturbance is caused by direct physiological consequences of a general medical condition [5].

In addition to these core symptoms, associated clinical findings include disturbance in psychomotor function, speech (thought process), sleep-wake cycle and mood. In clinical practice, it is common to classify delirium as: (a) hypoactive subtype, characterized by reduced alertness, sedation and reduction of motor activity; (b) hyperactive form, associated with hyper-vigilance, psychotic features (e.g. hallucinations and delusions) and agitation; and (c) a more prevalent, mixed subtype with overlapping features of the previous two forms. There is a lack of consensus about the definition of each subtype [33] and whether they have different underlying aetiology and pathophysiology [127]. However, there is growing evidence that hypoactive delirium is associated with worse outcomes compared to the other subtypes in elderly patients with dementia [147].

\section{Pathophysiology of delirium}

The pathophysiology of delirium involves the interplay between predisposing, precipitating and protective factors (Fig. 1). This model has been globally supported by numerous studies in medical and surgical samples which have identified several risk factors for delirium [22, 32, 69] (Table 1). Results from these studies are difficult to summarize and generalize because they involve different settings, measurements and methodologies. However, most consistently reported variables across studies include: dementia, medical illness, advanced age, abnormal blood urea nitrogen/creatinine ratio, abnormal sodium or potassium level, alcohol abuse, sensory impairment, and medications [40]. To reduce the analysis heterogeneity, it is useful to differentiate studies according to the setting (e.g. medical or surgical). Additionally, cardiac surgery has been classically distinguished from non-cardiac surgery as they differ with respect to factors with specific effects on pathophysiology of delirium such as extra-corporeal circulation or vascular dysfunction (Table 1B, C). Some studies have tried to determine the magnitude of risk associated with certain factors in order to establish the likelihood of delirium occurrence. For example, Inouye et al. [69] developed a four-factor model for risk stratification in medical patients in which presence of 1 or 2 factors had a 4.7 -fold increase in risk of delirium, while having 3 or 4 factors was 
Fig. 1 Multifactorial model of delirium

\section{Precipitating Factors}

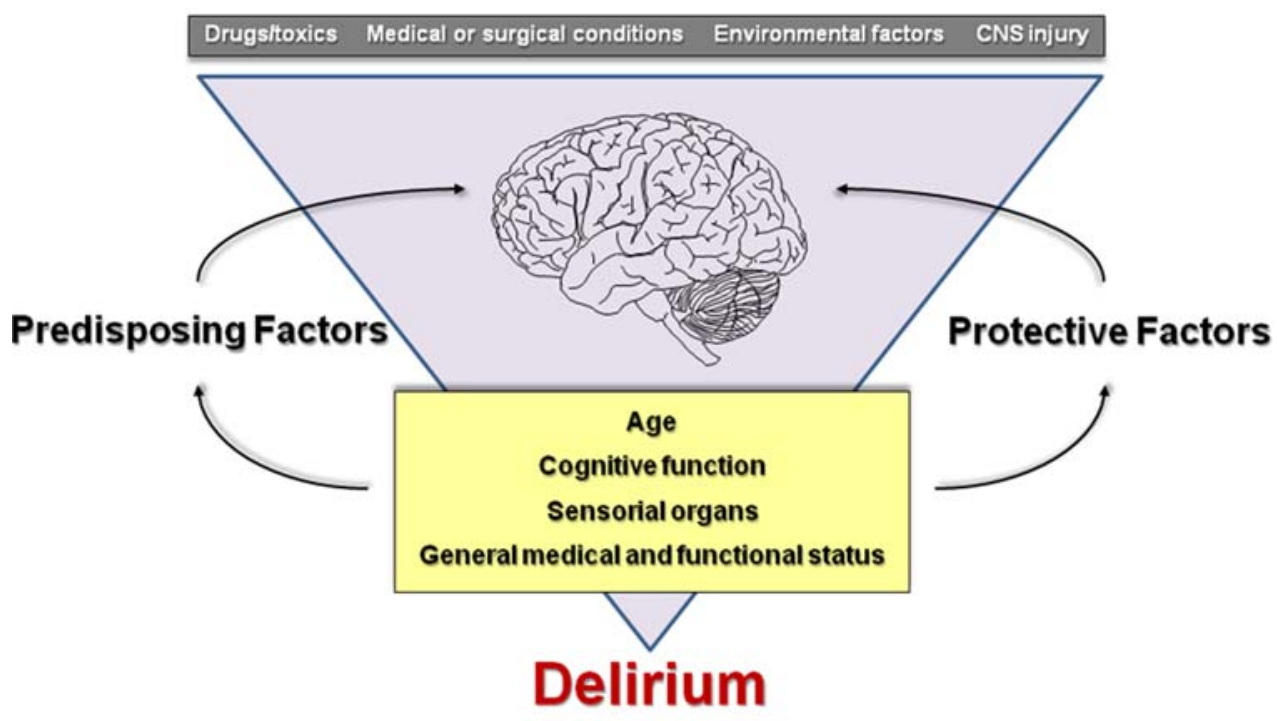

associated with a 9.5-fold risk (Table 1A). When applied to a non-cardiac surgical sample, this model proved to have good reliability [70].

Consequently, from a pathophysiological point of view, it is possible to conclude that in most cases of delirium there is interaction of multiple precipitating and predisposing factors, each one increasing the risk only marginally. While providing a general view about the pathogenesis of delirium, this does not elucidate the particular aetiological role of each risk factor. Given the small individual effect sizes of the several identified risk factors, delirium pathophysiology is likely to involve the interaction of multiple systems eliciting neurochemical abnormalities and brain dysfunction. Thus, cholinergic dysfunction has long been recognized to be involved in delirium pathophysiology and has been proposed as a "final pathway" to delirium regardless of the initial insult [133]. Other proposed hypothesis for delirium pathophysiology includes decreased oxidative metabolism, dysfunction of other neurotransmitters (dopamine, norepinephrine, glutamate, serotonin, and GABA), abnormal signal transduction, changes in bloodbrain barrier (BBB) permeability, endocrine abnormalities and increased inflammatory response [87].

\section{Clinical conditions with systemic inflammatory reactions to induce delirium}

Systemic inflammation is a prominent feature of numerous medical and surgical conditions associated with delirium,

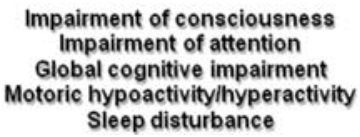

particularly when they involve tissue destruction and/or infection (Table 2). Thus, delirium is a frequent manifestation of a multiorganic dysfunction in the context of sepsis [124], a presenting clinical feature of underlying urinary tract infection or pneumonia (especially in demented elderly patients) or a complication following a major surgical procedure [102].

Peripheral infection activates the inflammatory cascade following direct recognition of specific components of microorganisms, such as lipopolysaccharide (LPS) in gramnegative bacteria, by resident and circulating phagocytes. A myriad of factors, such as tissue damage, blood loss, pain and anaesthetics can influence the function of immunocompetent cells and production of inflammatory mediators [78]. Even in a sterile setting, inflammation can be triggered following tissue destruction with the release of endogenous ligands, including heat shock proteins, hyaluronan, $\beta$-defensin and uric acid crystals which will activate similar innate receptor pathways [8]. Proinflammatory cytokines produced by resident macrophages and monocytes, including tumour necrosis factor alpha (TNF- $\alpha$ ) and interleukin (IL)-1, will, in turn, stimulate the expression of other mediators responsible for the recruitment of additional inflammatory cells to the injured site. Thus, what initially can be a localized immune reaction spreads to a generalized, systemic response with increased levels of cytokines in the circulation [12, 76] (Table 2). In cardiac surgery, cardiopulmonary bypass appears to be a major factor for activation of complement and secretion of proinflammatory cytokines contributing to post-operative 
Table 1 Factors reported to be associated with increased risk of delirium

\begin{tabular}{ll}
\hline (A) Medical setting [69] & \\
Visual impairment & Severe illness \\
Cognitive impairment & Dehydration \\
(B) Post-operative delirium (cardiac surgery) [22] & \\
Cerebrovascular disease & Diabetes mellitus \\
Peripheral vascular disease & Preoperative atrial fibrillation \\
Impaired left ventricular ejection fraction & Preoperative cardiogenic shock \\
Urgent operation & Intraoperative hemofiltration \\
Prolonged duration of surgery & High blood transfusion requirement \\
(C) Post-operative delirium (non-cardiac surgery) [32] & \\
Cognitive impairment & Older age \\
Functional impairment & Sensory impairment \\
Depression & Preoperative psychotropic drug use \\
Psychopathological symptoms & Medical comorbidity
\end{tabular}

Table 2 Medical or surgical conditions in which systemic inflammation is a feature of the pathophysiological process (see references for details)

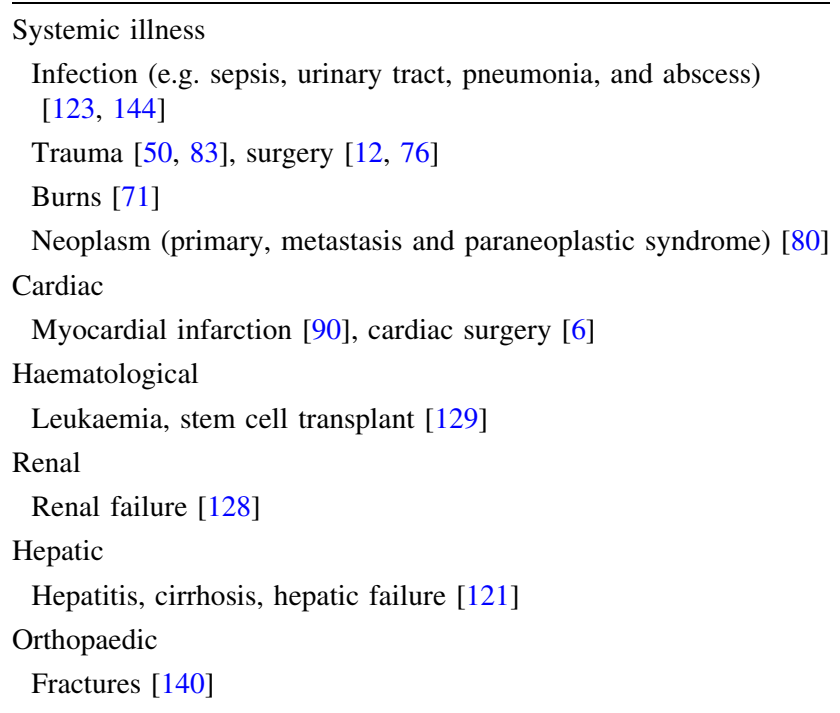

multi-organ dysfunction [6]. Reversely, off-pump procedures are associated with a lesser degree of plasmatic inflammatory mediators and improved function of major organs and post-operative cognitive performance [35]. Elevated levels of peripheral inflammatory mediators also correlate with post-operative organ dysfunction in noncardiac surgical procedures [53].

In many other medical or surgical conditions, in which delirium is a common occurrence, the release and production of pro-inflammatory mediators into the circulation is part of the pathophysiological process (Table 2). The extent to which a certain condition activates the inflammatory cascade depends on several factors, namely the intensity of physical/ surgical trauma and the likelihood of certain procedures to promote the release and diffusion of inflammatory mediators through the bloodstream (e.g. highly vascularized organs) [114]. Evidence directly implicating acute systemic inflammation in the occurrence of delirium comes from a study in which blood levels of IL-6 and IL-8 were higher in patients with post-operative delirium than in patients without delirium [140]. However, the clinical correlate of the peripheral inflammatory reaction, particularly to what extent it contributes to neuropsychiatric symptoms, has remained largely unexplored.

\section{Effects of acute systemic inflammation in the brain}

From acute systemic inflammation

to neuroinflammation

It is now well established that CNS resident cells react to the presence of peripheral immune signals, leading to production of cytokines and other mediators in the brain, cell proliferation and activation of hypothalamus-pituitary-adrenal axis through a complex system of interactions [31]. This innate response constitutes an important adaptive advantage because it coordinates a central response to combat acute peripheral infection. Several pathways involved in this communication include: (a) direct recognition of pathogenic signals or inflammatory mediators in areas where BBB is altered or absent; (b) energy-dependent transport systems for cytokines in the $\mathrm{BBB}$ or second messengers actively produced in the $\mathrm{BBB}$; (c) detection of peripheral immune activation by specialized sensory nerves carrying information into the brain via autonomic nervous system [63].

\section{Disruption of blood-brain barrier}

Animal studies consistently show that peripheral inflammatory stimuli are associated with functional and molecular 
Table 3 Functional and molecular changes in blood-brain barrier following acute systemic inflammatory stimuli

\begin{tabular}{|c|c|c|}
\hline Reference & Intervention & Results \\
\hline Huber [68] & $\begin{array}{l}\text { Formalin }(5 \%) \\
\lambda \text {-Carrageenan }(3 \%) \\
\text { CFA }(50 \%)\end{array}$ & $\begin{array}{l}\text { Increased }\left[{ }^{14} \mathrm{C}\right] \text { sucrose uptake at } 1 \mathrm{~h} \\
\text { Increase in } \mathrm{ZO}-1 \text { expression at } 1 \mathrm{~h} \\
\text { Increased }\left[{ }^{14} \mathrm{C}\right] \text { sucrose uptake } \\
\text { Increase in } \mathrm{ZO}-1 \text { and actin expression } \\
\text { Decrease in occluding expression }\end{array}$ \\
\hline Huber [67] & Pentobarbital sodium $+\lambda$-carrageenan $(3 \%)$ & $\begin{array}{l}\text { Increased }\left[{ }^{14} \mathrm{C}\right] \text { sucrose uptake at } 1,3,6 \text { and } 48 \mathrm{~h} \\
\text { Increased expression of ZO-1 at } 1,3 \text { and } 6 \mathrm{~h} \\
\text { Decreased expression of occludin at } 1,3,6,12 \text { and } 48 \mathrm{~h}\end{array}$ \\
\hline Brooks [17] & CFA $(50 \%)$ & $\begin{array}{l}\text { At } 72 \mathrm{~h} \text {, decreased occludin expression and increased expression of claudin } 3 \\
\text { and } 5 \text {. No changes in expression of ZO-1 and actin compared to controls } \\
\text { At } 72 \mathrm{~h} \text { increase in }\left[{ }^{14} \mathrm{C}\right] \text { sucrose uptake }\end{array}$ \\
\hline Brooks [18] & CFA $(50 \%)$ & $\begin{array}{l}\text { Increased }\left[{ }^{14} \mathrm{C}\right] \text { sucrose brain uptake at } 24 \text { and } 72 \mathrm{~h} \\
\text { Decreased expression of occludin at } 72 \mathrm{~h} \\
\text { Increased expression of JAM-1 at } 48 \mathrm{~h} \text { and decreased expression at } 72 \mathrm{~h} \\
\text { Decreased expression of claudin } 5 \text { at } 24 \mathrm{~h} \text {, increased expression at } 48 \text { and } 72 \mathrm{~h}\end{array}$ \\
\hline Huber [66] & $\lambda$-Carrageenan $(3 \%)$ & $\begin{array}{l}\text { Increased expression of ICAM- } 1 \text { in cerebral microvessels } \\
\text { No change in systemic proinflammatory cytokines during the early phase } \\
(1-6 \mathrm{~h}) \text {. Early microglia activation }(3 \mathrm{~h}) \text {. Increased levels of IL-1 and } \\
\text { IFN- } \gamma \text { at } 48-72 \mathrm{~h}\end{array}$ \\
\hline McCaffrey [92] & $\lambda$-Carrageenan $(3 \%)$ & Reduced amount of oligomeric occludin in cerebral microvessels \\
\hline
\end{tabular}

In each experiment $100 \mu$ of the inflammatory agent was subcutaneously injected into the plantar surface of the right hind paw of female rats CFA complete Freund's adjuvant

changes in BBB. Increased BBB permeability and altered expression of tight-junctional proteins were reported in three different inflammatory models (Table 3). Similarly, peripheral injection of LPS (the most commonly used model of acute systemic inflammation) induces, at very early stages, a cascade of events leading to BBB disruption, over-expression of adhesion molecules in endothelial cells, recruitment and infiltration of blood-derived leucocytes into brain tissue [61, 100, 118] (Table 4). Postmortem studies in human brain tissue also show considerable correlation between systemic inflammation and activation of endothelial and perivascular cells [135]. Although neuropathological confirmation of BBB disruption in human subjects is difficult to obtain, elevated blood levels of the $\beta$ subunit of S100 protein (S100- $\beta$ ) can be considered as an evidence of increased BBB permeability [89]. Thus, several conditions associated with acute systemic inflammation (e.g. septic shock and cardiac surgery) are presumably associated with BBB dysfunction $[2,48,99]$. Likewise, BBB disruption during episodes of delirium can be inferred from a recent study showing elevated serum levels of protein $S 100-\beta$ in acutely ill elderly medical patients with delirium [139]. Also, delirium during the early phases of septic shock is associated with leucoencephalopathy in brain magnetic resonance imaging (MRI), suggestive of BBB breakdown [119]. In addition to systemic inflammation, other factors affect the BBB microscopic structure and function, including hypoxia, ischaemia and pain [93, 104]. Conditions where these factors occur simultaneously (e.g. sepsis and surgery) are then more likely to promote the leakage of inflammatory agents circulating in the plasma through the BBB (Fig. 2).

\section{Reactions of CNS mediated by molecules from systemic circulation}

In the CNS, a diversity of blood-borne molecules, including LPS, are able to interact directly with receptors located on brain endothelial and parenchymal cells. Microglial cells are particularly capable to detect changes in CNS environment through a vast number of surface and nuclear receptors $[82,103]$. Thus, in mice CNS, cells lining the large blood-vessels and microglia express the Toll-like receptor 4 (TLR4; receptor for LPS). Its activation is a keystep for the elaboration of a CNS inflammatory response after administration of peripheral LPS [24]. There is also evidence that other mediators are implicated in the communication between the periphery and the brain, including TNF- $\alpha$ and monocyte chemoattractant protein $1[1,107$, 131] (Table 4). Once activated by receptor-ligand interaction, microglia exhibit, over a period ranging from minutes to few hours, morphological changes alongside 
Table 4 Animal studies: neuroinflammation following acute systemic inflammation

\begin{tabular}{|c|c|c|c|}
\hline Author & Sample & Intervention & Results \\
\hline Gautron [49] & 8-week-old rats (250-300 g) & LPS i.p. $(250 \mu \mathrm{g} / \mathrm{kg})$ & $\begin{array}{l}\text { Increased expression of markers of astrocyte activation (STAT3) } \\
\text { in areas lacking BBB at } 2 \mathrm{~h} \text { after treatment, with subsequent } \\
\text { propagation to hypothalamus, cortex, corpus callosum and } \\
\text { hippocampus }\end{array}$ \\
\hline Semmler [118] & $\begin{array}{l}\text { Male rats }(250-300 \mathrm{~g} \\
\text { age not specified })\end{array}$ & LPS i.p. $(10 \mathrm{mg} / \mathrm{kg})$ & $\begin{array}{l}\text { Increased iNOS expression in the striatum, hippocampus, midbrain } \\
\text { and cerebellum, at } 24 \mathrm{~h} \text {, compared to controls. Increased } \\
\text { number of astrocytes in the cortex, striatum and hippocampus. } \\
\text { Increased expression of apoptotic markers in the cortex, } \\
\text { hippocampus, midbrain and cerebellum }\end{array}$ \\
\hline \multirow[t]{4}{*}{ Qin [107] } & \multirow[t]{2}{*}{$\begin{array}{l}\text { TNF R1/R2+/+ mice } \\
\quad(8 \text { weeks old; } 20-22 \mathrm{~g})\end{array}$} & LPS i.p. $(5 \mathrm{mg} / \mathrm{kg})$ & $\begin{array}{l}\text { Increased levels of brain TNF- } \alpha \text { mRNA and protein with a peak at } \\
60 \text { min. Elevated levels of TNF- } \alpha \text { protein in the brain at } \\
14 \text { days, } 21 \text { days and } 10 \text { weeks; Microglia activation in cortex, } \\
\text { hippocampus and substantia nigra }\end{array}$ \\
\hline & & TNF- $\alpha$ i.p. $(0.25$ mg/kg) & $\begin{array}{l}\text { Increased levels of brain TNF- } \alpha \text { mRNA and protein. Increased } \\
\text { synthesis of other pro-inflammatory factors }\end{array}$ \\
\hline & \multirow{2}{*}{$\begin{array}{l}\text { TNF R1/R2-/- mice } \\
\quad \text { (8 weeks old; } 20-22 \mathrm{~g})\end{array}$} & LPS i.p. $(5 \mathrm{mg} / \mathrm{kg})$ & $\mathrm{TNF}-\alpha$ not detected in the brain \\
\hline & & TNF- $\alpha$ i.p. $(0.25$ mg/kg) & $\mathrm{TNF}-\alpha$ not detected in the brain \\
\hline \multirow[t]{2}{*}{ Alexander [1] } & TNFR $+/+$ mice $(8$ weeks old $)$ & LPS i.p. (0.15 mg) & $\begin{array}{l}\text { Increased levels of TNF- } \alpha \text { and TNFR } 1 \text { mRNA in the brain, } \\
\text { especially in the hippocampal region }\end{array}$ \\
\hline & TNF R1-/- mice ( 8 weeks old) & LPS i.p. (0.15 mg) & $\begin{array}{l}\text { Less apoptosis, less neutrophil infiltration, less astrocytosis, less } \\
\text { iNO mRNA expression compared with TNFR }+/+ \text { mice }\end{array}$ \\
\hline \multirow[t]{4}{*}{$\begin{array}{l}\text { Thompson } \\
\text { [131] }\end{array}$} & \multirow[t]{2}{*}{$\begin{array}{l}\mathrm{MCP}-1+/+ \text { mice }(20-25 \mathrm{~g} \\
\quad \text { age not specified })\end{array}$} & \multirow[t]{2}{*}{ LPS i.p. (5 mg/kg) } & $\begin{array}{l}\text { Increased levels of MCP-1 in the serum and brain up to } 24 \mathrm{~h} \\
\text { compared to saline controls }\end{array}$ \\
\hline & & & $\begin{array}{l}\text { Increased levels of IL-1 } \beta \text { and TNF-a in plasma, entorhinal cortex, } \\
\text { frontal cortex and hippocampus compared to saline controls }\end{array}$ \\
\hline & \multirow[t]{2}{*}{$\begin{array}{l}\text { MCP-1-/- mice }(20-25 \mathrm{~g} \text {; } \\
\quad \text { age not specified })\end{array}$} & \multirow[t]{2}{*}{ LPS i.p. (5 mg/kg) } & $\begin{array}{l}\text { Increased levels of IL- } 1 \beta \text { and TNF-a in plasma compared with } \\
\text { LPS-treated MCP- } 1+/+ \text { mice }\end{array}$ \\
\hline & & & $\begin{array}{l}\text { Increased levels of IL- } 1 \beta \text { and TNF-a in entorhinal cortex, frontal } \\
\text { cortex and hippocampus compared to saline controls but lower } \\
\text { than in LPS-treated MCP- } 1+/+ \text { mice }\end{array}$ \\
\hline Nishioku [100] & 8-week-old mice & LPS i.p. (20 mg/kg) & $\begin{array}{l}\text { Increased BBB permeability, microglial activation, structural } \\
\text { alterations in pericytes and basal lamina of the hippocampus }\end{array}$ \\
\hline
\end{tabular}

$B B B$ blood-brain barrier, $i N O S$ inducible nitric oxide synthase, LPS i.p. lipopolysaccharide intra-peritoneal, $M C P-1$ monocyte chemoattractant protein-1, TNF R1/2 TNF- $\alpha$ receptor $1 / 2$. Whenever appropriate, the genotype of the animals is indicated with $-/-$ (knockout) or $+/+$ (wild-type)

with expression of several molecules including MHC class I, CD45, CD4, ICAM-I, VLA-4, LFA-1 and Fas [79, 82] (Fig. 2). Following stimulation, some subpopulations of microglia also express MHC class II and B7 molecules [98]. These changes are coupled with microglial production of proinflammatory cytokines (TGF- $\beta 1$, IL- $1 \beta$, TNF $\alpha$, IGF-1), reactive oxygen species (ROS) and expansion of microglial population through proliferation of resident cells and recruitment from adjacent areas or blood [14].

The initial recognition of peripheral inflammatory stimuli in the BBB is followed by a cascade of events leading to a coordinated modulation of adjacent cells and structures of the neurovascular unit [26] (Table 4; Fig. 2). Endothelial cells, astrocytes, microglia, pericytes and basal lamina interact through a wide range of mediators including cytokines, chemokines and metalloproteinases [23].
Astrocytes are most important in propagating signals generated in the neurovascular unit to other brain regions exerting a multimodal control on synaptic transmission, neuronal excitability and cerebral blood flow [141].

Acute systemic inflammation and neurocognitive dysfunction

Systemic inflammatory insults are associated not only with full-blown delirium but they are also implicated in more subtle neuropsychiatric symptoms. Symptoms similar to but not meeting the criteria of full delirium have long been recognized in people treated with recombinant IFN [88] and occurrence of sub-syndromal delirium has been associated with adverse outcomes in elderly individuals [27]. In healthy human subjects experimental treatment with bacterial 
Fig. 2 Recognition and propagation of peripheral immune stimuli in the CNS. The initial interaction of circulating inflammatory mediators (e.g. cytokines and lipopolysaccharide) with the neurovascular unit occurs through a vast number of receptors and is associated with an increased paracellular permeability of the

blood-brain-barrier. In addition to systemic inflammation, other factors affect the integrity of BBB including hypoxia, ischaemia and pain. Recognition of peripheral inflammatory stimuli in the BBB is followed by a cascade of events leading to microglia activation and subsequent modulation of adjacent cells including astrocytes and neurons (represented with dashed reciprocal arrows)

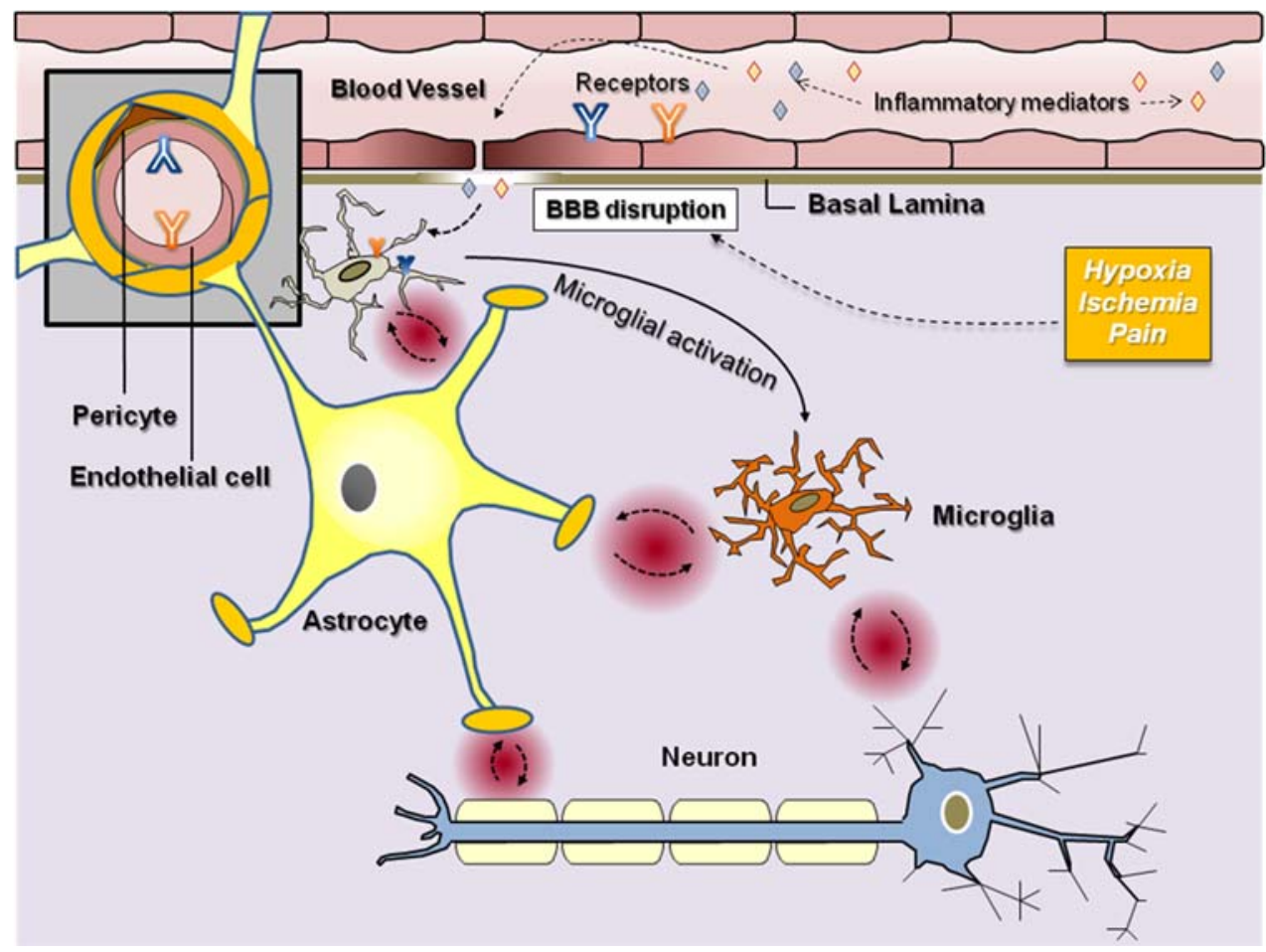

endotoxin produces a dose-dependent effect in cognitive function, emotional state and sleep [96, 110]. Circulating cytokines are increased by very low dose LPS $(0.2 \mathrm{ng} / \mathrm{kg})$ and these changes have a negative impact in declarative memory [75]. More recently, a study using functional MRI documented that injection of peripheral LPS in healthy volunteers evoked a sustained systemic inflammatory reaction and psychomotor retardation in cognitive tasks and this correlated with enhanced activity in the left substantia nigra (SN) [21].

Similarly, the elegant series of rodents' studies using LPS, cytokines and surgical procedures established that peripheral immune stimulation induces an acute and transient state characterized by sleepiness, anorexia and apathy together with cognitive impairment [132]. These symptoms are part of the sickness behaviour syndrome, reproducing the acute neurobehavioural response to infection. It should be stated in advance that aspects of the experimental design used in animal studies have potential confounding factors affecting the data interpretation [28]. Also, significant obvious differences exist between the complexity of cognitive, emotional and behavioural repertoires between rodents and humans. So, rather than being used as comprehensive models to mimic the multiple aspects of delirium, animal experiments can be useful in examining the pathophysiology underlying particular neurobehavioral responses to acute systemic inflammation.

Animal experiments using several learning and memory paradigms have consistently shown that peripheral immune system activation has a significant impact on cognition. For example, impairments in memory consolidation of previously learned tasks and disruption of working memory were reported in animals following LPS-induced immune stimulation [105]. Temporary impairment in spatial learning and memory, coupled with microglial activation and expression of proinflammatory cytokines, was also described in animals undergoing splenectomy. These changes were not observed in rats devoid of intervention and those with anaesthesia only [143] (Table 5).

Cognitive changes following acute systemic inflammation are thought to result from cellular and molecular synergic interactions in different brain regions and particularly in the hippocampus. Pro-inflammatory IL-1 has long been recognized to impair hippocampal-dependent fear conditioning and to have an important role in neurophysiological processes of memory consolidation, possibly modulating synaptic plasticity [109]. IL-6 has also been implicated in hippocampal dysfunction [126] (Table 5). In contrast, IL-10 seems to counterbalance the effects of IL-1 and IL-6, inhibiting behavioural and cognitive consequences of peripheral inflammation [77, 112] (Table 5). Likewise, decreased hippocampal decreased expression of brain-derived growth factor (BDNF) and increased oxidative stress with mitochondrial dysfunction have also been implicated in deficits of learning and memory associated with neuroinflammation $[101,130]$. These data suggest that the combined action of locally brain produced ROS, proinflammatory cytokines, metalloproteinases, NO 
Table 5 Animal studies: acute systemic inflammation and neurocognitive dysfunction

\begin{tabular}{|c|c|c|c|}
\hline Author & Sample & Intervention & Results \\
\hline \multirow{5}{*}{$\begin{array}{l}\text { Sparkman } \\
\text { [126] }\end{array}$} & \multirow{3}{*}{$\begin{array}{l}\text { IL- } 6+/+ \text { rats } \\
\quad(3-5 \text { months old })\end{array}$} & \multirow[t]{3}{*}{ LPS i.p. $(100 \mu \mathrm{g})$} & Increase in plasma IL- $1 \beta$, TNF- $\alpha$, IL- 6 and IL-10 \\
\hline & & & $\begin{array}{l}\text { Impairment performance in a matching-to-place task in the water maze } \\
\text { at day } 2 \text { after compared with saline-injected rats }\end{array}$ \\
\hline & & & Increased expression of IL- $1 \beta$ and TNF- $\alpha$ in the hippocampus \\
\hline & \multirow{2}{*}{$\begin{array}{l}\text { IL- } 6-/- \text { rats } \\
\quad(3-5 \text { months old })\end{array}$} & \multirow[t]{2}{*}{ LPS i.p. $(100 \mu \mathrm{g})$} & Increase in plasma IL- $1 \beta, \mathrm{TNF}-\alpha$, IL- 6 and IL-10 \\
\hline & & & $\begin{array}{l}\text { No impairments in performance in the water maze compared with controls } \\
\text { No increased expression of IL- } 1 \beta \text { and TNF- } \alpha \text { in the hippocampus }\end{array}$ \\
\hline \multirow{2}{*}{$\begin{array}{r}\text { Tanaka } \\
{[130]}\end{array}$} & \multirow{2}{*}{$\begin{array}{l}\text { Male rats (age and } \\
\text { weight not specified) }\end{array}$} & \multirow{2}{*}{$\begin{array}{l}\text { Intra-hippocampal LPS } \\
\quad \text { for } 5 \text { consecutive days } \\
\quad(20 \mu \mathrm{g} / \text { day })\end{array}$} & Increased expression of IL- 1 and TNF- $\alpha$ at $2 \mathrm{~h}$ co-localized with microglia \\
\hline & & & $\begin{array}{l}\text { After sub-acute treatment with LPS for } 5 \text { days animals presented memory } \\
\text { and learning deficits in a passive avoidance task, long-term activation } \\
\text { of microglia and decreased expression of BDNF and TrkB }\end{array}$ \\
\hline \multirow{2}{*}{$\begin{array}{l}\text { Noble } \\
\quad[101]\end{array}$} & \multirow{2}{*}{$\begin{array}{l}\text { 10- to } 12 \text {-week-old mice } \\
\quad(35-40 \mathrm{~g})\end{array}$} & \multirow[t]{2}{*}{ LPS i.p. $(250 \mu \mathrm{g})$} & Memory impairment in a Y-maze test \\
\hline & & & $\begin{array}{l}\text { Increased ROS and NO production associated with GSH depletion in brain } \\
\text { mitochondria }\end{array}$ \\
\hline \multirow[t]{2}{*}{ Wan [143] } & \multirow{2}{*}{$\begin{array}{l}\text { 90-day-old rats } \\
\quad(300-350 \mathrm{~g})\end{array}$} & Anaesthesia only & No differences from control rats. No glial activation \\
\hline & & Splenectomy & $\begin{array}{l}\text { Impaired cognitive performance, microglial activation and increased } \\
\text { production of IL-1 } \beta \text { mRNA in the hippocampus at post-operative days } \\
1 \text { and } 3\end{array}$ \\
\hline \multirow{4}{*}{$\begin{array}{l}\text { Krzyszton } \\
\quad[77]\end{array}$} & \multirow{2}{*}{$\begin{array}{l}\text { IL }-10+/+ \text { mice } \\
\quad(3 \text { and } 12 \text { months old })\end{array}$} & \multirow[t]{2}{*}{ LPS i.p. $(10 \mu \mathrm{g})$} & Motor performance and learning not different from controls receiving saline \\
\hline & & & $\begin{array}{l}\text { Increased levels of IL- } 1 \beta, \mathrm{TNF}-\alpha \text {, and IL- } 6 \text { in cerebellum, cortex, } \\
\text { hippocampus and striatum compared to controls }\end{array}$ \\
\hline & \multirow[t]{2}{*}{$\begin{array}{l}\text { IL-10-/- mice } \\
\quad(3 \text { and } 12 \text { months old })\end{array}$} & \multirow[t]{2}{*}{ LPS i.p. $(10 \mu \mathrm{g})$} & $\begin{array}{l}\text { Deficits in motor performance and learning compared with animals injected } \\
\text { with saline }\end{array}$ \\
\hline & & & $\begin{array}{l}\text { Increased levels of IL- } 1 \mathrm{~b}, \mathrm{TNF}-\alpha \text {, and IL- } 6 \text { in cerebellum, cortex, } \\
\text { hippocampus and striatum compared to IL-10-/- animals receiving } \\
\text { saline, with markedly higher levels than in LPS-treated IL-10+/+ animals } \\
\text { in } 3 \text { of } 4 \text { brain regions }\end{array}$ \\
\hline \multirow[t]{4}{*}{ Lee $[81]$} & \multirow{4}{*}{$\begin{array}{l}\text { 25-30 g male mice } \\
\quad \text { (age not specified) }\end{array}$} & \multirow[t]{4}{*}{ LPS i.p. $(250 \mu \mathrm{g} / \mathrm{kg})$} & Cognitive impairment in passive avoidance test and water maze test \\
\hline & & & $\begin{array}{l}\text { Increased levels of } A \beta 1-42 \text { and decreased levels of } A \beta 1-40 \text { in the } \\
\text { hippocampus }\end{array}$ \\
\hline & & & $\begin{array}{l}\text { Increased expression of APP, BACE and C99 with increased activity } \\
\text { of } \beta \text { and } \gamma \text {-secretase in the cortex and hippocampus }\end{array}$ \\
\hline & & & $\begin{array}{l}\text { Increased number of activated astrocytes and apoptotic cells in the } \\
\text { hippocampus }\end{array}$ \\
\hline \multirow[t]{8}{*}{$\begin{array}{l}\text { Richwine } \\
\text { [112] }\end{array}$} & \multirow[t]{3}{*}{$\begin{array}{l}\text { IL-10+/+ } \\
\quad \text { (3-month-old mice) }\end{array}$} & \multirow[t]{3}{*}{ LPS i.p. $(10 \mu \mathrm{g})$} & $\begin{array}{l}\text { Reduced locomotor behaviour at } 4 \mathrm{~h} \text { and recovering to } 72 \% \text { of controls } \\
\text { at } 24 \mathrm{~h}\end{array}$ \\
\hline & & & $\begin{array}{l}\text { Increased expression of IL-1, IL- } 6 \text { and TNF- } \alpha \text { in the hippocampus, } \\
\text { hypothalamus, cortex and cerebellum }\end{array}$ \\
\hline & & & Reduced expression of hippocampal BDNF \\
\hline & \multirow[t]{5}{*}{$\begin{array}{l}\text { IL-10-/- } \\
\quad(3-\text { month-old mice })\end{array}$} & Saline i.p. & $\begin{array}{l}\text { Lower levels of BDNF in the hippocampus compared to saline-injected } \\
\text { IL- } 10+/+ \text { mice }\end{array}$ \\
\hline & & \multirow[t]{4}{*}{ LPS i.p. $(10 \mu \mathrm{g})$} & Reduced locomotor behaviour at $4 \mathrm{~h}$ with $35 \%$ of controls at $24 \mathrm{~h}$ \\
\hline & & & $\begin{array}{l}\text { Cytokine levels significantly increased compared with LPS-treated } \\
\text { IL- } 10+/+ \text { mice at } 4 \mathrm{~h}\end{array}$ \\
\hline & & & $\begin{array}{l}\text { Expression of hippocampal BDNF significantly lower than LPS-treated } \\
\text { IL- } 10+/+ \text { mice }\end{array}$ \\
\hline & & & Impaired performance in a matching-to-place task in the water maze at $24 \mathrm{~h}$ \\
\hline
\end{tabular}

$\overline{A P P}$ amyloid precursor protein, $B A C E \beta$-site APP cleavage enzyme, $B D N F$ brain-derived neurotrophic factor, $G S H$ reduced glutathione, $L P S$ lipopolysaccharide, $R O S$ reactive oxygen species. Whenever appropriate, the genotype of the animals is indicated with $-/-(\mathrm{knockout})$ or $+/+$ (wild-type) 
and chemokines induce functional changes in neurons, affecting processes such as synaptic plasticity and longterm potentiation, and can impair learning and memory [91].

There is evidence that microglia and astrocyte activation by peripheral immune challenge can promote $\mathrm{Bax} / \mathrm{Bcl}-2$ imbalance and affect intraparenchymal brain cell survival [118]. In fatal cases of septic shock, Sharshar et al. [120] found neuronal and glial apoptosis within the cerebral autonomic centres in human brains, which correlated with the expression of endothelial inducible nitric oxide synthase (iNOS). Lee et al. [81] suggested that the activation of amyloidogenesis associated with neuroinflammation could be an important mechanism implicated in the apoptotic neuronal death and neurocognitive dysfunction induced by systemic immune stimuli (Table 5). The cascade of events occurring within the CNS following peripheral immune stimulation can affect neuronal viability even at long term. Thus, a single exposure to systemic LPS or TNF- $\alpha$ induced a significant loss of dopaminergic neurons in the $\mathrm{SN}$ first observed at 7 months (23\% loss) and showing increasing severity at 10 months after the insult (47\% loss) [107].

Overall, these data demonstrate that acute exposure to systemic inflammation elicits a neurocognitive clinical syndrome analogous to delirium coupled with an underlying neuroinflammatory reaction affecting synaptic and neuronal function. As the synthesis of acetylcholine is particularly sensitive to homeostatic changes in the brain, neuroinflammation promotes a cholinergic deficit with associated imbalances in other neurotransmitters including dopamine, serotonin and norepinephrine [64]. The current scientific knowledge cannot fully explain the exact mechanisms by which these structural, functional and neurochemical changes are translated into cognitive, behavioural and emotional symptoms. Data from anaesthetics demonstrate that some core symptoms of delirium (e.g. impaired consciousness) likely involve changes in dynamic aspects of neuronal activity affecting brain's ability to integrate information through functional disconnection between different anatomical structures [3]. Also, distinct clinical features may arise due to impairment of brain areas known to be the neuroanatomical substrates of alertness, awareness and attention [149]. It is also possible that the neuroinflammatory pathway may only be responsible for some specific symptoms of delirium.

\section{Effects of acute systemic inflammation in the brain: influence of ageing and neurodegeneration}

Individuals with advanced age and/or with prior cognitive impairment (including dementia) are at greater risk of developing delirium. There is also increasing evidence that the occurrence of delirium predicts adverse cognitive outcomes at long term in subjects with or without pre-existing dementia [46, 86]. This suggests that delirium and dementia share overlapping pathophysiological features which arise in the context of the ageing process, the common risk factor to both conditions. It is therefore of major interest to explore the influence of ageing and neurodegenerative conditions in the CNS response to systemic inflammation.

Effects of acute systemic inflammation in the ageing brain

Several aspects of the innate and cellular immunity are affected as age increases, a process known as "immunosenescence" [52]. Elderly individuals show a weaker adaptive immunity rendering them more prone to infection and less responsive to vaccination or experimental treatment with LPS [20, 41]. At the same time, the ageing process is associated with a sustained two- to fourfold increase in baseline levels of circulating inflammatory mediators including cytokines and acute phase proteins [74].

Cognitive performance is generally preserved in human normal ageing apart from a slowed processing speed and impairment in spatial memory [148]. Several neuropathological, cellular and molecular changes are associated with ageing, including a decline in brain volume and weight, loss of synaptic density and plasticity as well as variable changes in dendritic branching [136]. Studies in cognitively intact elderly show a strong positive correlation between age and altered tau protein metabolism with accumulation of neurofibrillary tangles and a variable deposition of corpora amylacea, argyrophilic grains, neuromelanin, and lipofuscin in various brain regions [72, 95]. Equally important is the finding of an increased number of activated, enlarged or dystrophic microglia in the aged brain of nondemented subjects paired with immunophenotypic changes such as up-regulation of MHC class II [47]. While it remains controversial whether these cells represent an activated rather than a senescent state, it is clear that microglial cells undergo age-related morphological and functional changes which can induce a pro-inflammatory environment in the aged brain [13]. It is likely that this microglial "primed" state with increased reactivity is the consequence of several factors including chronic accumulation of minor insults resulting in DNA damage and in the production of advanced glycation end products of tissue and cell surface proteins [36].

Neuropathological evidence linking neuroinflammation to clinical signs of brain dysfunction is illustrated by a casereport in which widespread neuroinflammatory changes 
Fig. 3 The effects of acute systemic inflammation in the brain: the influence of ageing

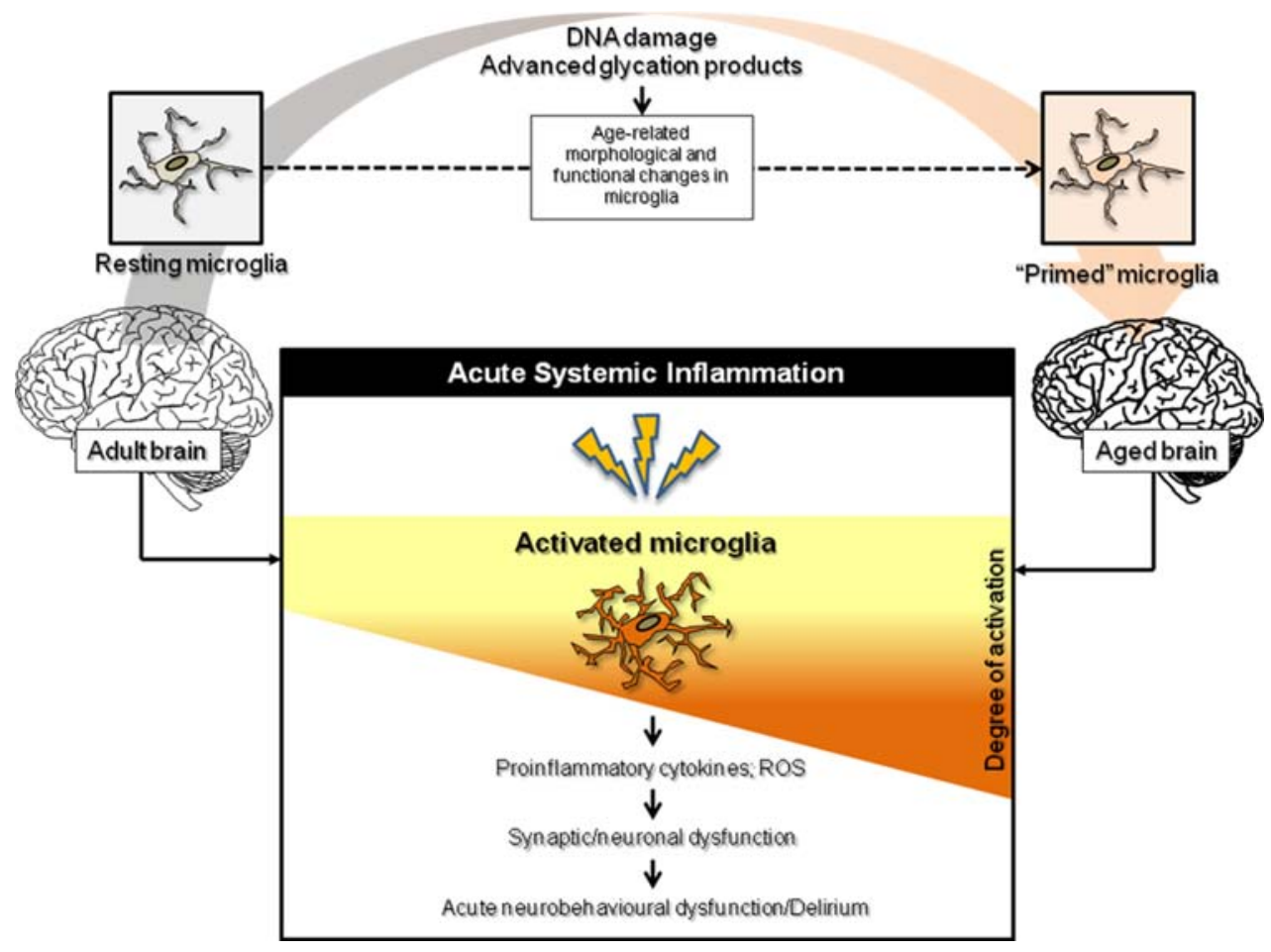

induced by relapsing polychondritis were responsible for clinical features of Dementia with Lewy bodies [54]. Similar reports are useful to explore the neuropathological correlates of chronic, but not acute, systemic inflammatory conditions in an aged non-degenerative brain. Thus, animal studies remain the only way to document in detail how the ageing process can influence the CNS response to acute systemic inflammation (Fig. 3).

As in humans, brains of aged mice devoid of neurodegenerative disease show an increased expression of genes associated with heightened microglial reactivity [108]. Following peripheral administration of LPS, old mice show a delayed recovery from sickness behaviour, compared to adult animals, reflecting an exaggerated and protracted neuroinflammatory response [51] (Table 6). These findings were replicated following administration of intracerebrovascular LPS [65] which, by excluding any potential cytokine amplification at the periphery, support that ageing is associated with increased CNS immune responsiveness (Table 6). Chen et al. [25] reported that old mice consistently showed higher basal levels of microglia density and inflammatory cytokines in the hippocampus compared with their young adults counterparts. Peripheral inoculation of LPS increased hippocampal expression of cytokine mRNAs (IL-1, IL-6, TNF- $\alpha$ ) in both groups (old and young adults), but significantly more in the old mice. Furthermore, old mice treated with LPS showed the most severe disruption in hippocampal capacity to integrate new information in relation to any of the other groups. In another study, Henry et al. [55] reported an increased microglial expression of MHC II in aged mice, a phenotype indicating a primed or reactive state (Table 6). Following LPS peripheral challenge, primed microglia were activated to a greater extent than MHC II-negative microglia and were highly responsible for the exaggerated production of IL-1 $\beta$. These findings are in line with those of Richwine et al. [111] who found higher steady-state expression of pro-inflammatory cytokines and decreased expression of neurotrophic factors in the hippocampus of aged mice compared with adults (Table 6). This was associated with increased vulnerability of CA1 neurons to LPS-induced neuroinflammation as shown by structural changes with decreased dendrite complexity compared to adult controls. Interestingly, even minor surgical trauma was associated with increased IL- $1 \beta$ hippocampal expression of aged but not adult animals on the first post-operative day [113] (Table 6).

Acute systemic inflammation in dementia

Dementia is a syndrome characterized by a progressive and irreversible decline in multiple cognitive domains. This is manifested by memory impairment and other associated cognitive deficits (e.g. aphasia, apraxia, agnosia, disturbance in executive functioning) which cause significant interference in social and occupational functioning [5].

Patients with dementia represent up to $42 \%$ of all admissions in acute medical wards mainly due to urinary tract or respiratory infections [115]. Delirium complicates 
Table 6 Animal studies: the effects of acute systemic inflammation in the ageing brain

\begin{tabular}{|c|c|c|c|}
\hline Author & Sample & Intervention & Results \\
\hline \multirow{4}{*}{$\begin{array}{l}\text { Godbout } \\
\text { [51] }\end{array}$} & \multirow{2}{*}{$\begin{array}{l}\text { 3- to 6-month-old } \\
\text { rats }\end{array}$} & Saline i.p. & \\
\hline & & LPS i.p. $(10 \mu \mathrm{g})$ & Increased levels of inflammatory cytokines in the brain \\
\hline & \multirow[t]{2}{*}{$\begin{array}{l}\text { 20- to } 24 \text {-month-old } \\
\text { rats }\end{array}$} & Saline i.p. & $\begin{array}{l}\text { Gene transcriptional profile suggestive of primed microglia and increased inflammation } \\
\text { in the brain }\end{array}$ \\
\hline & & LPS i.p. $(10 \mu \mathrm{g})$ & $\begin{array}{l}\text { Prolonged sickness behaviour and exaggerated production of brain inflammatory } \\
\text { cytokines compared with younger animals }\end{array}$ \\
\hline \multirow[t]{4}{*}{ Huang [65] } & \multirow{2}{*}{$\begin{array}{l}\text { 3- to } 4 \text {-month-old } \\
\text { mice }\end{array}$} & Saline icv & \\
\hline & & LPS (10 ng) icv & Increased levels of IL-1 $\beta$, IL- 6 and TNF- $\alpha$ in cerebellum and hippocampus \\
\hline & \multirow{2}{*}{$\begin{array}{l}\text { 20- to } 24 \text {-month-old } \\
\text { mice }\end{array}$} & Saline icv & Increased expression of reactive microglial markers compared to adults \\
\hline & & LPS (10 ng) icv & $\begin{array}{l}\text { Protracted sickness behaviour associated with prolonged cytokine overexpression } \\
\text { compared to adults }\end{array}$ \\
\hline \multirow[t]{4}{*}{ Chen [25] } & \multirow{2}{*}{$\begin{array}{l}\text { 3- to 4-month-old } \\
\text { mice }\end{array}$} & Saline i.p. & \\
\hline & & $\begin{array}{l}\text { LPS i.p. } \\
\quad(0.33 \mathrm{mg} / \mathrm{kg})\end{array}$ & Increased levels of inflammatory cytokine mRNA in hippocampus \\
\hline & \multirow[t]{2}{*}{$\begin{array}{l}\text { 22- to } 24 \text {-month-old } \\
\text { mice }\end{array}$} & Saline i.p. & $\begin{array}{l}\text { Increased number of microglial cells and higher levels of IL-1 } \beta \text { in hippocampus } \\
\text { compared to adult mice treated with saline }\end{array}$ \\
\hline & & $\begin{array}{l}\text { LPS i.p. } \\
\quad(0.33 \mathrm{mg} / \mathrm{kg})\end{array}$ & $\begin{array}{l}\text { Higher levels of inflammatory cytokine mRNA in hippocampus compared to adult mice } \\
\text { treated with LPS. Deficits in spatial working memory }\end{array}$ \\
\hline \multirow{4}{*}{$\begin{array}{l}\text { Richwine } \\
\text { [111] }\end{array}$} & \multirow{2}{*}{$\begin{array}{l}\text { 3- to 6-month-old } \\
\text { mice }\end{array}$} & Saline i.p. & \\
\hline & & $\begin{array}{l}\text { LPS i.p. } \\
\quad(0.33 \mathrm{mg} / \mathrm{kg})\end{array}$ & Increase in hippocampal expression of IL-1 $\beta$, IL- 6 and TNF- $\alpha$ mRNA peaking at $4 \mathrm{~h}$ \\
\hline & \multirow[t]{2}{*}{$\begin{array}{l}\text { 22- to } 24 \text {-month-old } \\
\text { mice }\end{array}$} & Saline i.p. & $\begin{array}{l}\text { Increased expression of MHC II mRNA and lower expression of NGF and BDNF in the } \\
\text { hippocampus compared to adults }\end{array}$ \\
\hline & & $\begin{array}{l}\text { LPS i.p. } \\
\quad(0.33 \mathrm{mg} / \mathrm{kg})\end{array}$ & $\begin{array}{l}\text { Higher levels of hippocampal pro-inflammatory cytokines compared to adults. } \\
\text { Decreased arborisation of apical dendritic tree compared to old controls }\end{array}$ \\
\hline \multirow[t]{2}{*}{$\begin{array}{c}\text { Rosczyk } \\
{[113]}\end{array}$} & $\begin{array}{l}\text { 4- to } 6 \text {-month-old } \\
\text { mice }\end{array}$ & $\begin{array}{l}\text { Minor abdominal } \\
\text { surgery }\end{array}$ & Increased levels of IL- $1 \beta$ mRNA in hippocampus of aged mice \\
\hline & $\begin{array}{l}\text { 23- to } 25 \text {-month-old } \\
\text { mice }\end{array}$ & & \\
\hline \multirow[t]{4}{*}{ Henry [55] } & \multirow{2}{*}{$\begin{array}{l}\text { 3- to 4-month-old } \\
\text { mice }\end{array}$} & Saline i.p. & \\
\hline & & $\begin{array}{l}\text { LPS i.p. } \\
\quad(0.33 \mathrm{mg} / \mathrm{kg})\end{array}$ & Increased expression of IL- $1 \beta$ and IL-10 mRNA in microglia \\
\hline & \multirow{2}{*}{$\begin{array}{l}\text { 18- to } 20 \text {-month-old } \\
\text { mice }\end{array}$} & Saline i.p. & Increased expression of MHC II in microglia compared to adults \\
\hline & & $\begin{array}{l}\text { LPS i.p. } \\
\qquad(0.33 \mathrm{mg} / \mathrm{kg})\end{array}$ & More pronounced increased in IL-1 $\beta$ and IL-10 than in adult microglia \\
\hline
\end{tabular}

$B D N F$ brain-derived neurotrophic factor, $i c v$ intracerebroventricular, LPS lipopolysaccharide, $M H C$ major histocompatibility complex, $N G F$ nerve growth factor

24-89\% of hospitalizations for elderly patients with dementia predicting poor cognitive and functional outcomes [10, 44, 94]. Therefore, differentiating delirium from pre-existing dementia is clinically relevant and has been recommended as a routine practice [16]. Classically, delirium and dementia have been differentiated based on clinical features (impaired versus clear consciousness) and natural course (rapid onset and fluctuating versus progressive onset and stable). Still, there is a substantial clinical overlap between the two conditions and the crucial issue in most cases is to identify and remove the reversible components of the clinical picture. Delirium superimposed in dementia is associated, as in non-demented patients, with deregulation of neurotransmitter systems [137]. Also, there is no strong evidence that delirium has distinct features when occurring in patients with prior dementia [134]. However, recent studies suggest that level of consciousness and hyperactive motor features can be more frequently seen among delirious demented patients than in nondemented patients with delirium $[15,38]$.

Chronic neuroinflammatory events are known to play an important role in dementia, particularly in AD. In fact, one of the hallmarks of $\mathrm{AD}$ is presence of activated microglia and reactive astrocytes in $A \beta$ plaques and neurofibrillary 
tangles together with a broad variety of inflammatory mediators before the development of extensive tau-related neuropathology and brain atrophy [120]. Interaction of $A \beta$ with microglial cell surface receptors, in the presence of synergic molecules such as complement cascade proteins, induces the activation of microglia with subsequent phagocytosis of amyloid and production of inflammatory cytokines by these cells [39]. Interestingly, the LPS receptor $\mathrm{CD} 14$ interacts with fibrillar $\mathrm{A} \beta$ suggesting that a structural mimicry exists between aggregated $A \beta$ fibrils and pathogenic-associated microbial patterns [85]. There is evidence that microglia activation leads to a reduction in $\mathrm{A} \beta$ plaques supporting their neuroprotective role [30]. However, reactivity of microglia and astrocytes against $A \beta$ can promote or exacerbate the neuropathological changes of $\mathrm{AD}[43,97]$. In fact, inflammatory conditions can impair microglial capacity for internalization of amyloid precursor protein (APP) peptides [142] and affect the expression and function of APP secretases [116] favouring the accumulation of A $\beta$ fibrils. Similarly, microglia-derived IL-1 $\beta$ and IL-6 can induce tau hyperphosphorylation through activation of the p38-MAPK and cyclin-dependent kinase 5 (cdk5), respectively [73].

In addition to up-regulation of a broad variety of inflammatory mediators in the AD brain, serum levels of inflammatory markers have been associated with a risk of cognitive decline in several cross-sectional and longitudinal studies, albeit with conflicting results [4, 117]. Moreover, impaired BBB function has been implicated in several pathogenic cascades in $\mathrm{AD}$ [9] presumably rendering $\mathrm{AD}$ patients more prone to detrimental effects of acute systemic CNS inflammation. To clarify this, few attempts have been made to explore the impact of acute systemic inflammation on the natural course of $\mathrm{AD}$. In a study by Holmes et al. [62], acute systemic inflammatory events were associated with a twofold increase in the rate of cognitive decline over a 6-month period. There was no association between the occurrence of those episodes with delirium (assessed at 2, 4 and 6 months) [62]. This could have resulted from the under-recognition of delirium in the sample and to the mild nature of majority of the acute systemic inflammatory events. Thus, it seems that acute systemic inflammation interferes with the natural course of $\mathrm{AD}$, even if it is not severe enough to elicit delirium symptoms. Additional data on this topic is provided by Higuchi et al. [60] who, although not using specific instruments to evaluate delirium, found elevated blood levels of IL-1 $\beta$ in AD patients early before and during periods of agitation. Clearly, longitudinal studies documenting the immediate impact of acute systemic inflammatory episodes on the mental state of patients are needed.
Further insight about the effect of acute systemic inflammation in the pathophysiology of dementia is provided by pre-clinical research. Animals previously infected with murine prion disease as a model of chronic neurodegeneration have microglia with morphologic changes typical of activation, with altered morphology and upregulation of surface markers, but without elevated levels of cytokines or iNOS [29]. Intraperitoneal LPS injection induces an intense neuroinflammatory response in animals with ongoing neurodegeneration which is associated with neuronal death as demonstrated by increased number of TUNEL-positive cells showing apoptotic morphology [29].

Transgenic APP mouse models of AD are also useful to explore the effects of LPS treatment in neuroinflammation and amyloid deposition. While studies consistently demonstrate that LPS administration to amyloid-depositing transgenic mice results in expected neuroinflammatory changes (microglia activation, and increase of inflammatory mediators), findings regarding amyloid deposition are conflicting. Thus, some studies reported increased deposition of $A \beta$ in mice brain parenchyma following treatment with LPS [106, 122], whereas others have demonstrated a decrease in A $\beta$ load following LPS exposure, supporting a role for microglia in $A \beta$ removal $[34,57,58]$. With disease progression, expression of microglial $A \beta$-binding receptors and $A \beta$-degrading enzymes is reduced and coupled with over-expression of pro-inflammatory cytokines. These changes are likely to impair $A \beta$ processing and removal by microglia, potentially contributing to accelerate the disease course [59].

In summary, there are clinical and neuropathological evidences suggesting that pre-existing dementia significantly increases the susceptibility of CNS to the deleterious effects of acute systemic inflammation. Inversely, acute systemic inflammation can aggravate the pathophysiological changes associated with the ongoing neurodegenerative process. Although these findings have not been typically conceptualized as being central to delirium, they support an aetiological role for the neuroinflammatory pathway both in delirium and dementia, proving a pathophysiological explanation for the intimate relation between the two conditions.

\section{Perspectives on prevention and treatment of delirium}

Management of delirium involves the early identification and immediate removal of precipitating factors complemented with supportive measures and, in general, symptomatic use of neuroleptic medication is not recommended as the primary management of delirium. In some patients with hyperactive symptoms, such as agitation or hallucinations, haloperidol 
remains the preferred drug but it should be used cautiously [16]. In fact, in elderly subjects with dementia, the use of anti-psychotics to control symptoms of agitation has been associated with increased mortality [7]. So, considerable interest exists whether the evidence reviewed in this paper can bring new approaches for the prevention and management of delirium. In this regard, some agents with anti-inflammatory action were useful to reduce LPS-induced microglial/astrocyte activation, production of pro-inflammatory mediators and facilitating recovery from neurobehavioural symptoms [11, 56, 84, 118]. Likewise, in models of experimental sepsis there is evidence that blockage of C5a, a small peptide derived from complement activation, can prevent BBB breakdown [45]. It remains to be determined how these findings can be applied to humans. Nevertheless, development of pharmacological strategies that can modulate the neuroinflammatory pathway may well offer new therapeutic tools to be used in the management of delirium.

\section{Conclusions}

Delirium is a complex and dynamic condition characterized by non-linear interactions among aetiologically distinct factors and by graded and continuous changes in cognitive, behavioural and emotional symptoms. Clinically, it is often difficult to recognize and to differentiate from other psychiatric disorders, as it involves subtle changes in a wide range of neurocognitive and psychomotor domains. Not surprisingly, delirium has resisted to

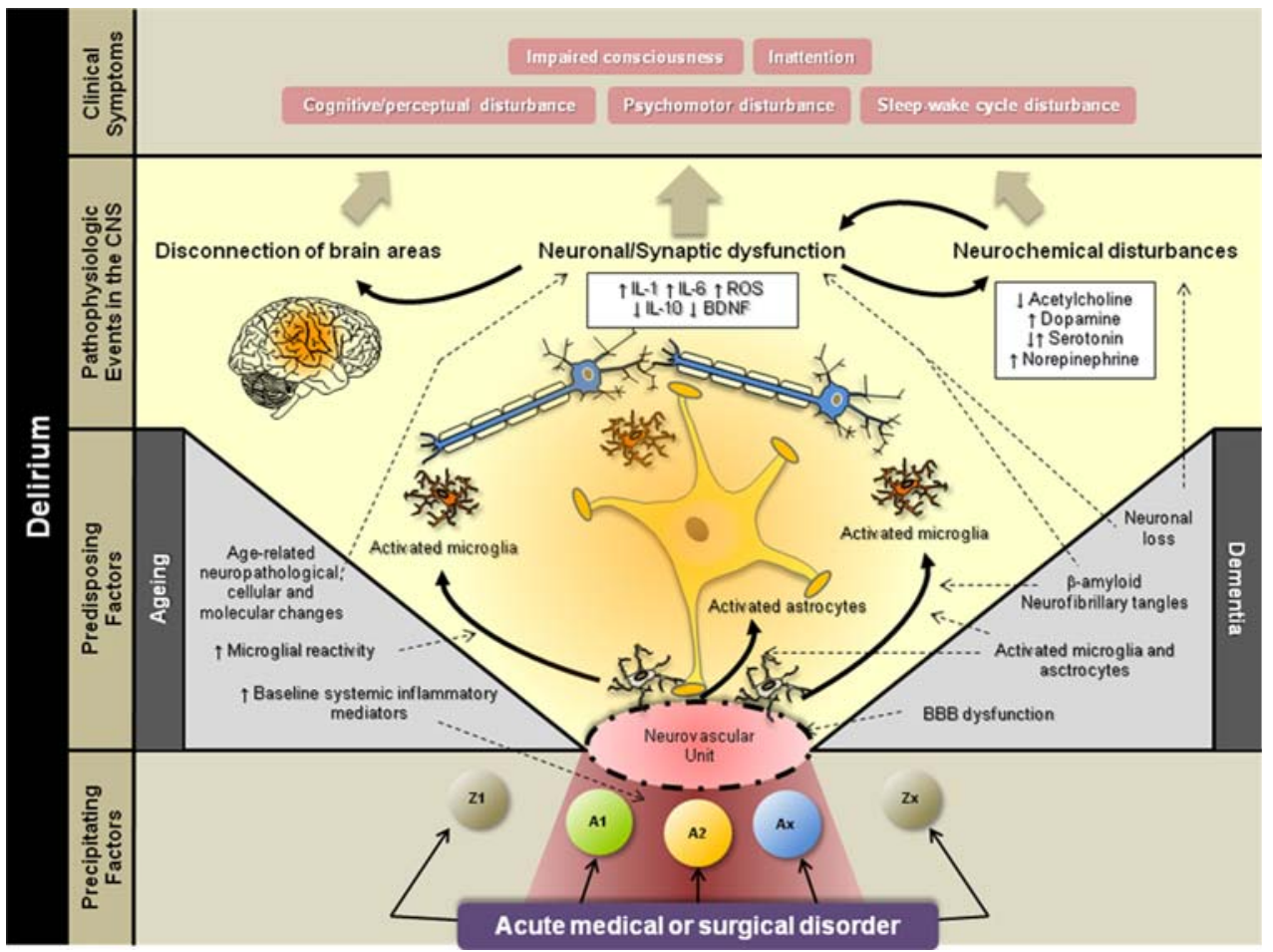

Fig. 4 The neuroinflammatory pathway of delirium. The majority of conditions associated with delirium are characterized by significant aetiological and pathophysiological heterogeneity with complex interactions of multiple factors (systemic inflammation, dehydration, electrolytic imbalance, pharmacological agents, ischaemia, hypoxia, pain, etc.). Activation of the systemic inflammatory response is a feature of several acute medical or surgical disorders, particularly when involving tissue destruction and/or infection. In such cases, numerous molecules (e.g. lipopolysaccharide and pro-inflammatory cytokines) circulating in the bloodstream (represented as $A 1, A 2, A x$ ) elicit a cascade of functional and structural changes within the neurovascular unit leading to the activation of microglial cells and astrocytes. The acute neuroinflammatory reaction affects physiological processes implicated in neuronal and synaptic function with consequent neurochemical disturbances and functional disconnection between different anatomical structures. These neurobiological changes underlie acute and transient failure of high integrative cognitive, behavioural and emotional functions as seen in delirium. When present, other factors (e.g. dehydration, electrolytic imbalance, pharmacological agents, ischaemia, hypoxia, pain, etc., represented as $Z 1, Z x$ ) while not directly activating a systemic inflammatory response, can exert synergic effects with the neuroinflammatory pathway through alternative pathophysiological routes. The contribution of the neuroinflammatory pathway to promote the symptoms of delirium is likely to be especially relevant in elderly subjects or in patients with prior dementia. As discussed in the text, several pathophysiological changes associated with both conditions render the brain more vulnerable to the deleterious effect of acute systemic inflammation (represented with dashed arrows). $B B B$ blood-brain barrier, $B D N F$ brain-derived growth factor, $C N S$ central nervous system, ROS reactive oxygen species 
the formulation of consistent etiopathogenic models able to integrate the already identified risk factors with their underlying clinical correlates.

In this review we have attempted to provide a comprehensive perspective about the contribution of the neuroinflammatory pathway in the pathogenesis of delirium. Thus, there is compelling evidence that the presence of peripheral immune signals culminates, through a complex system of communication involving the $\mathrm{BBB}$, in functional and structural changes in brain parenchymal cells, including microglia, astrocytes and neurons. These neuroinflammatory changes are associated with acute onset of cognitive, behavioural and emotional disturbances. While studies in humans could provide the best evidence linking acute systemic inflammation to the specific symptoms of delirium, the research in this field remains very scarce. So, despite all the limitations, animal models are useful to evaluate the neuropathological correlates of acute psychomotor and cognitive disturbances associated with acute systemic inflammation.

By gathering data from both sources it is apparent that a neuroinflammatory response is an important event associated with delirium whenever the subject is exposed to a diverse range of peripheral conditions, especially when involving infection, tissue destruction and systemic inflammation. Brain homeostasis, neurotransmission and neurophysiological functions of several regulatory centres in the brain can be compromised by the neurotoxic effect of cytokines, ROS, NO and other inflammatory mediators, generated mainly by microglial and astrocytic cells. Predictably, when such events occur, dysfunction of cerebral cortical areas and sub-cortical structures is likely to result in a reduced capacity to interact with the environment and to integrate stimuli within the cognitive experience. This provides a plausible neurobiological rational supported by a temporal association linking neuroinflammation phenomena to the failure of high integrative cognitive, behavioural and emotional functions observed in delirium (Fig. 4).

This is further pronounced in elderly subjects and in patients with dementia. As discussed, in both cases several regulatory networks involved in neuroprotection are characteristically dysregulated and microglial cells are overactivated in baseline conditions. It is, therefore, likely that people with advanced age and/or neurodegenerative disorders would be at increased risk to develop delirium because, even when other factors are excluded, the neuroinflammatory response would be amplified due to a combination of primed microglia, increased production of pro-inflammatory mediators and decreased level of protective mechanisms (Fig. 4). Another important question is whether neuroinflammatory changes cooccurring with delirium have a role in the development of neurodegeneration and cognitive impairment at long term. As shown, evidence from clinical and animal studies reveals that beyond the acute phase, acute systemic inflammation can elicit a sustained dysregulation in neuroinflammatory events potentially aggravating pre-existing neurodegeneration and cognitive decline.

The evidence about the intricate neuroinflammatory processes underlying acute neurocognitive and behavioural symptoms following systemic inflammation insults provide powerful insight for the formulation of a comprehensive etiopathogenic model of delirium. In the context of a multifactorial, complex and dynamic model, the neuroinflammatory pathway can be a major process underlying delirium when the individual is exposed to an acute systemic inflammatory condition (e.g. infection or surgery). This model does not exclude, of course, the contribution of other factors known to be relevant to the syndrome such as hypoxia, dehydration, electrolytic imbalance and pharmacological agents. Presumably, the synergic interaction among these factors can result in a complex and simultaneous acute failure of several physiological pathways involved in brain homeostasis.

The progressive understanding of the fundamental neurobiological processes underlying delirium will allow a more precise definition and classification of this syndrome looking behind its confusing plethora of symptoms and taking into account its pathogenesis. This knowledge is also crucial to guide the search for specific and sensitive biomarkers enabling the risk stratification, the diagnosis at the pre-symptomatic stage, monitoring the clinical evolution and predicting the clinical outcome. Ultimately, this will also have implication on the development of more effective approaches to prevent the occurrence of delirium and slow the progression or retard the clinical manifestations of neurodegenerative disorders.

Acknowledgments We are grateful to Pedro Batista and Vasco Nogueira for critical reading of this manuscript and helpful comments. We would like to thank the anonymous reviewers for their useful and constructive comments, as well as Mrs. Alyson Goldwater and Mrs. Isabel Amoedo for secretarial support and editing the text. This work was supported by a BIAL (Porto, Portugal) grant to JC and Alzheimer Society (London, UK) award to EBM-L.

\section{References}

1. Alexander JJ, Jacob A, Cunningham P, Hensley L, Quigg RJ (2008) TNF is a key mediator of septic encephalopathy acting through its receptor, TNF receptor-1. Neurochem Int 52(3):447456

2. Ali MS, Harmer M, Vaughan R (2000) Serum S100 protein as a marker of cerebral damage during cardiac surgery. Br J Anaesth 85(2):287-298

3. Alkire MT, Hudetz AG, Tononi G (2008) Consciousness and anesthesia. Science 322(5903):876-880

4. Alley DE, Crimmins EM, Karlamangla A, Hu P, Seeman TE (2008) Inflammation and rate of cognitive change in highfunctioning older adults. J Gerontol A Biol Sci Med Sci 63(1):50-55 
5. American Psychiatric Association (2000) Diagnostic and statistical manual of mental disorders, 4th edn. American Psychiatric Association, Washington, DC (text rev)

6. Asimakopoulos G (1999) Mechanisms of the systemic inflammatory response. Perfusion 14(4):269-277

7. Ballard C, Waite J (2006) The effectiveness of atypical antipsychotics for the treatment of aggression and psychosis in Alzheimer's disease. Cochrane Database Syst Rev 25(1):CD003476

8. Barton GM (2008) A calculated response: control of inflammation by the innate immune system. J Clin Invest 118(2):413-420

9. Bell RD, Zlokovic BV (2009) Neurovascular mechanisms and blood-brain barrier disorder in Alzheimer's disease. Acta Neuropathol 118(1):103-113

10. Bellelli G, Frisoni GB, Turco R, Lucchi E, Magnifico F, Trabucchi M (2007) Delirium superimposed on dementia predicts 12-month survival in elderly patients discharged from a postacute rehabilitation facility. J Gerontol A Biol Sci Med Sci 62(11):1306-1309

11. Benicky J, Sánchez-Lemus E, Pavel J, Saavedra JM (2009) Anti-inflammatory effects of angiotensin receptor blockers in the brain and the periphery. Cell Mol Neurobiol 29(6-7): 781-792

12. Bjornsson GL, Thorsteinsson L, Gudmundsson KO, Jonsson H Jr, Gudmundsson S, Gudbjornsson B (2007) Inflammatory cytokines in relation to adrenal response following total hip replacement. Scand J Immunol 65(1):99-105

13. Blasko I, Stampfer-Kountchev M, Robatscher P, Veerhuis R, Eikelenboom P, Grubeck-Loebenstein B (2004) How chronic inflammation can affect the brain and support the development of Alzheimer's disease in old age: the role of microglia and astrocytes. Aging Cell 3(4):169-176

14. Block ML, Zecca L, Hong JS (2007) Microglia-mediated neurotoxicity: uncovering the molecular mechanisms. Nat Rev Neurosci 8(1):57-69

15. Boettger S, Passik S, Breitbart W (2009) Delirium superimposed on dementia versus delirium in the absence of dementia: phenomenological differences. Palliat Support Care 7(4):495-500

16. British Geriatrics Society. Guidelines for the Prevention, Diagnosis and Management of Delirium in Older People in Hospital. BGS, 2006 (http://www.bgs.org.uk/Publications/ Clinical\%20Guidelinesclinical_1-2_delirium.htm)

17. Brooks TA, Hawkins BT, Huber JD, Egleton RD, Davis TP (2005) Chronic inflammatory pain leads to increased bloodbrain barrier permeability and tight junction protein alterations. Am J Physiol Heart Circ Physiol 289(2):H738-H743

18. Brooks TA, Ocheltree SM, Seelbach MJ et al (2006) Biphasic cytoarchitecture and functional changes in the BBB induced by chronic inflammatory pain. Brain Res 1120(1):172-182

19. Bruce AJ, Ritchie CW, Blizard R, Lai R, Raven P (2007) The incidence of delirium associated with orthopedic surgery: a meta-analytic review. Int Psychogeriatr 19(2):197-214

20. Bruunsgaard H, Pedersen AN, Schroll M, Skinhoj P, Pedersen BK (1999) Impaired production of proinflammatory cytokines in response to lipopolysaccharide (LPS) stimulation in elderly humans. Clin Exp Immunol 118(2):235-241

21. Brydon L, Harrison NA, Walker C, Steptoe A, Critchley HD (2008) Peripheral inflammation is associated with altered substantia nigra activity and psychomotor slowing in humans. Biol Psychiatry 63(11):1022-1029

22. Bucerius J, Gummert JF, Borger MA et al (2004) Predictors of delirium after cardiac surgery delirium: effect of beating-heart (off-pump) surgery. J Thorac Cardiovasc Surg 127(1):57-64

23. Cardona AE, Li M, Liu L, Savarin C, Ransohoff RM (2008) Chemokines in and out of the central nervous system: much more than chemotaxis and inflammation. J Leukoc Biol 84(3): $587-594$
24. Chakravarty S, Herkenham M (2005) Toll-like receptor 4 on nonhematopoietic cells sustains CNS inflammation during endotoxemia, independent of systemic cytokines. J Neurosci 25(7): 1788-1796

25. Chen J, Buchanan JB, Sparkman NL, Godbout JP, Freund GG, Johnson RW (2008) Neuroinflammation and disruption in working memory in aged mice after acute stimulation of the peripheral innate immune system. Brain Behav Immun 22(3): 301-311

26. Choi YK, Kim KW (2008) Blood-neural barrier: its diversity and coordinated cell-to-cell communication. BMB Rep 41(5):345-352

27. Cole M, McCusker J, Dendukuri N, Han L (2003) The prognostic significance of subsyndromal delirium in elderly medical inpatients. J Am Geriatr Soc 51(6):754-760

28. Cunningham C, Sanderson DJ (2008) Malaise in the water maze: untangling the effects of LPS and IL-1b on learning. Brain Behav Immun 22(8):1117-1127

29. Cunningham C, Wilcockson DC, Campion S, Lunnon K, Perry VH (2005) Central and systemic endotoxin challenges exacerbate the local inflammatory response and increase neuronal death during chronic neurodegeneration. J Neurosci 25(40):9275-9284

30. D'Andrea MR, Cole GM, Ard MD (2004) The microglial phagocytic role with specific plaque types in the Alzheimer disease brain. Neurobiol Aging 25(5):675-683

31. Dantzer R, O'Connor JC, Freund GG, Johnson RW, Kelley KW (2008) From inflammation to sickness and depression: when the immune system subjugates the brain. Nat Rev Neurosci 9(1): $46-56$

32. Dasgupta M, Dumbrell AC (2006) Preoperative risk assessment for delirium after noncardiac surgery: a systematic review. J Am Geriatr Soc 54(10):1578-1589

33. de Rooij SE, Schuurmans MJ, van der Mast RC, Levi M (2005) Clinical subtypes of delirium and their relevance for daily clinical practice: a systematic review. Int $\mathrm{J}$ Geriatr Psychiatry 20(7):609-615

34. DiCarlo G, Wilcock D, Henderson D, Gordon M, Morgan D (2001) Intrahippocampal LPS injections reduce Abeta load in APP + PS1 transgenic mice. Neurobiol Aging 22(6):1007-1012

35. Diegeler A, Hirsch R, Schneider F et al (2000) Neuromonitoring and neurocognitive outcome in off-pump versus conventional coronary bypass operation. Ann Thorac Surg 69(4):1162-1166

36. Dilger RN, Johnson RW (2008) Aging, microglial cell priming, and the discordant central inflammatory response to signals from the peripheral immune system. J Leukoc Biol 84(4):932-939

37. Ebersoldt M, Sharshar T, Annane D (2007) Sepsis-associated delirium. Intensive Care Med 33(6):941-950

38. Edlund A, Lundström M, Sandberg O, Bucht G, Brännström B, Gustafson Y (2007) Symptom profile of delirium in older people with and without dementia. J Geriatr Psychiatry Neurol 20(3): $166-171$

39. Eikelenboom P, Veerhuis R, Scheper W, Rozemuller AJ, van Gool WA, Hoozemans JJ (2006) The significance of neuroinflammation in understanding Alzheimer's disease. J Neural Transm 113(11):1685-1695

40. Elie M, Cole MG, Primeau FJ, Bellavance F (1998) Delirium risk factors in elderly hospitalized patients. J Gen Intern Med 13(3):204-212

41. El Yousfi M, Mercier S, Breuillé D et al (2005) The inflammatory response to vaccination is altered in the elderly. Mech Ageing Dev 126(8):874-881

42. Engel GL, Romano J (1959) Delirium, a syndrome of cerebral insufficiency. J Neuropsychiatry Clin Neurosci 16(4):526-538

43. Farfara D, Lifshitz V, Frenkel D (2008) Neuroprotective and neurotoxic properties of glial cells in the pathogenesis of Alzheimer's disease. J Cell Mol Med 12(3):762-780 
44. Fick DM, Agostini JV, Inouye SK (2002) Delirium superimposed on dementia: a systematic review. J Am Geriatr Soc 50(10):1723-1732

45. Flierl MA, Stahel PF, Rittirsch D et al (2009) Inhibition of complement C5a prevents breakdown of the blood-brain barrier and pituitary dysfunction in experimental sepsis. Crit Care 13(1):R12

46. Fong TG, Jones RN, Shi P et al (2009) Delirium accelerates cognitive decline in Alzheimer disease. Neurology 72(18): $1570-1575$

47. Frank MG, Barrientos RM, Biedenkapp JC, Rudy JW, Watkins LR, Maier SF (2006) mRNA up-regulation of MHC II and pivotal pro-inflammatory genes in normal brain aging. Neurobiol Aging 27(5):717-722

48. Gao F, Harris DN, Sapsed-Byrne S (1999) Time course of neurone-specific enolase and S-100 protein release during and after coronary artery bypass grafting. Br J Anaesth 82(2):266267

49. Gautron L, Lafon P, Chaigniau M, Tramu G, Layé S (2002) Spatiotemporal analysis of signal transducer and activator of transcription 3 activation in rat brain astrocytes and pituitary following peripheral immune challenge. Neuroscience 112(3): 717-729

50. Girard TD, Pandharipande PP, Ely EW (2008) Delirium in the intensive care unit. Crit Care 12(3):S3

51. Godbout JP, Chen J, Abraham J et al (2005) Exaggerated neuroinflammation and sickness behavior in aged mice following activation of the peripheral innate immune system. FASEB $\mathbf{J}$ 19(10):1329-1331

52. Gomez CR, Nomellini V, Faunce DE, Kovacs EJ (2008) Innate immunity and aging. Exp Gerontol 43(8):718-728

53. Groeneveld AB, Raijmakers PG, Rauwerda JA, Hack CE (1997) The inflammatory response to vascular surgery-associated ischaemia and reperfusion in man: effect on postoperative pulmonary function. Eur J Vasc Endovasc Surg 14(5):351-359

54. Head E, Starr A, Kim RC et al (2006) Relapsing polychondritis with features of dementia with Lewy bodies. Acta Neuropathol 112(2):217-225

55. Henry CJ, Huang Y, Wynne AM, Godbout JP (2009) Peripheral lipopolysaccharide (LPS) challenge promotes microglial hyperactivity in aged mice that is associated with exaggerated induction of both pro-inflammatory IL-1beta and anti-inflammatory IL-10 cytokines. Brain Behav Immun 23(3):309-317

56. Henry CJ, Huang Y, Wynne A et al (2008) Minocycline attenuates lipopolysaccharide (LPS)-induced neuroinflammation, sickness behavior, and anhedonia. J Neuroinflamm 5:15

57. Herber DL, Roth LM, Wilson D et al (2004) Time-dependent reduction in Abeta levels after intracranial LPS administration in APP transgenic mice. Exp Neurol 190(1):245-253

58. Herber DL, Mercer M, Roth LM et al (2007) Microglial activation is required for Abeta clearance after intracranial injection of lipopolysaccharide in APP transgenic mice. J Neuroimmune Pharmacol 2(2):222-231

59. Hickman SE, Allison EK, El Khoury J (2008) Microglial dysfunction and defective beta-amyloid clearance pathways in aging Alzheimer's disease mice. J Neurosci 28(33):8354-8360

60. Higuchi M, Hatta K, Honma T et al. (2009) Association between altered systemic inflammatory interleukin-1beta and natural killer cell activity and subsequently agitation in patients with alzheimer disease. Int J Geriatr Psychiatry. doi:10.1002/gps.2381

61. Hofer S, Bopp C, Hoerner C et al (2008) Injury of the blood brain barrier and up-regulation of ICAM-1 in polymicrobial sepsis. J Surg Res 146:276-281

62. Holmes C, Cunningham C, Zotova E et al (2009) Systemic inflammation and disease progression in Alzheimer disease. Neurology 73(10):768-774
63. Hopkins SJ (2007) Central nervous system recognition of peripheral inflammation: a neural, hormonal collaboration. Acta Biomed 78(Suppl 1):231-247

64. Hshieh TT, Fong TG, Marcantonio ER, Inouye SK (2008) Cholinergic deficiency hypothesis in delirium: a synthesis of current evidence. J Gerontol A Biol Sci Med Sci 63(7):764-772

65. Huang Y, Henry CJ, Dantzer R, Johnson RW, Godbout JP (2008) Exaggerated sickness behavior and brain proinflammatory cytokine expression in aged mice in response to intracerebroventricular lipopolysaccharide. Neurobiol Aging 29(11):1744-1753

66. Huber JD, Campos CR, Mark KS, Davis TP (2006) Alterations in blood-brain barrier ICAM-1 expression and brain microglial activation after lambda-carrageenan-induced inflammatory pain. Am J Physiol Heart Circ Physiol 290(2):H732-H740

67. Huber JD, Hau VS, Borg L, Campos CR, Egleton RD, Davis TP (2002) Blood-brain barrier tight junctions are altered during a 72-h exposure to lambda-carrageenan-induced inflammatory pain. Am J Physiol Heart Circ Physiol 283(4):H1531-H1537

68. Huber JD, Witt KA, Hom S, Egleton RD, Mark KS, Davis TP (2001) Inflammatory pain alters blood-brain barrier permeability and tight junctional protein expression. Am J Physiol Heart Circ Physiol 280(3):H1241-H1248

69. Inouye SK, Viscoli CM, Horwitz RI et al (1993) A predictive model for delirium in hospitalized elderly medical patients based on admission characteristics. Ann Intern Med 119: 474-481

70. Kalisvaart KJ, Vreeswijk R, de Jonghe JF, van der Ploeg T, van Gool WA, Eikelenboom P (2006) Risk factors and prediction of postoperative delirium in elderly hip-surgery patients: implementation and validation of a medical risk factor model. J Am Geriatr Soc 54(5):817-822

71. Keck M, Herndon DH, Kamolz LP, Frey M, Jeschke MG (2009) Pathophysiology of burns. Wien Med Wochenschr 159(13-14): 327-336

72. Keller JN (2006) Age-related neuropathology, cognitive decline, and Alzheimer's disease. Ageing Res Rev 5(1):1-13

73. Kitazawa M, Yamasaki TR, LaFerla FM (2004) Microglia as a potential bridge between the amyloid beta-peptide and tau. Ann N Y Acad Sci 1035:85-103

74. Krabbe KS, Pedersen M, Bruunsgaard H (2004) Inflammatory mediators in the elderly. Exp Gerontol 39(5):687-699

75. Krabbe KS, Reichenberg A, Yirmiya R, Smed A, Pedersen BK, Bruunsgaard H (2005) Low-dose endotoxemia and human neuropsychological functions. Brain Behav Immun 19(5):453460

76. Kragsbjerg P, Holmberg H, Vikerfors T (1995) Serum concentrations of interleukin-6, tumour necrosis factor-alpha, and $\mathrm{C}$-reactive protein in patients undergoing major operations. Eur J Surg 161(1):17-22

77. Krzyszton CP, Sparkman NL, Grant RW et al (2008) Exacerbated fatigue and motor deficits in interleukin-10-deficient mice after peripheral immune stimulation. Am J Physiol Regul Integr Comp Physiol 295(4):R1109-R1114

78. Kurosawa S, Kato M (2008) Anesthetics, immune cells, and immune responses. J Anesth 22(3):263-277

79. Ladeby R, Wirenfeldt M, Garcia-Ovejero D et al (2005) Microglial cell population dynamics in the injured adult central nervous system. Brain Res Brain Res Rev 48(2):196-206

80. Le Bitoux MA, Stamenkovic I (2008) Tumor-host interactions: the role of inflammation. Histochem Cell Biol 130(6):10791090

81. Lee JW, Lee YK, Yuk DY et al (2008) Neuro-inflammation induced by lipopolysaccharide causes cognitive impairment through enhancement of beta-amyloid generation. J Neuroinflamm 29;5:37 
82. Lee YB, Nagai A, Kim SU (2002) Cytokines, chemokines, and cytokine receptors in human microglia. J Neurosci Res 69(1): 94-103

83. Lenz A, Franklin GA, Cheadle WG (2007) Systemic inflammation after trauma. Injury 38(12):1336-1345

84. Lin ST, Wang Y, Xue Y, Feng DC, Xu Y, Xu LY (2008) Tetrandrine suppresses LPS-induced astrocyte activation via modulating IKKs-IkappaBalpha-NF-kappaB signaling pathway. Mol Cell Biochem 315(1-2):41-49

85. Liu Y, Walter S, Stagi M et al (2005) LPS receptor (CD14): a receptor for phagocytosis of Alzheimer's amyloid peptide. Brain 102(Pt 8):1778-1789

86. MacLullich AM, Beaglehole A, Hall RJ, Meagher DJ (2009) Delirium and long-term cognitive impairment. Int Rev Psychiatry $21(1): 30-42$

87. Maldonado JR (2008) Pathoetiological model of delirium: a comprehensive understanding of the neurobiology of delirium and an evidence-based approach to prevention and treatment. Crit Care Clin 24(4):789-856 ix

88. Malek-Ahmadi P, Hilsabeck RC (2007) Neuropsychiatric complications of interferons: classification, neurochemical bases, and management. Ann Clin Psychiatry 19(2):113-123

89. Marchi N, Cavaglia M, Fazio V, Bhudia S, Hallene K, Janigro D (2004) Peripheral markers of blood-brain barrier damage. Clin Chim Acta 342(1-2):1

90. Marx N, Neumann FJ, Ott I et al (1997) Induction of cytokine expression in leukocytes in acute myocardial infarction. J Am Coll Cardiol 30(1):165-170

91. McAfoose J, Baune BT (2009) Evidence for a cytokine model of cognitive function. Neurosci Biobehav Rev 33(3):355-366

92. McCaffrey G, Seelbach MJ, Staatz WD et al (2008) Occludin oligomeric assembly at tight junctions of the blood-brain barrier is disrupted by peripheral inflammatory hyperalgesia. J Neurochem 106(6):2395-2409

93. McCaffrey G, Willis CL, Staatz WD et al (2009) Occludin oligomeric assemblies at tight junctions of the blood-brain barrier are altered by hypoxia and reoxygenation stress. J Neurochem 110(1):58-71

94. McCusker J, Cole M, Dendukuri N, Belzile E, Primeau F (2001) Delirium in older medical inpatients and subsequent cognitive and functional status: a prospective study. CMAJ 165(5):575583

95. Mukaetova-Ladinska EB, Harrington CR, Roth M, Wischik CM (1996) Alterations in tau protein metabolism during normal aging. Dementia 7(2):95-103

96. Mullington J, Korth C, Hermann DM et al (2000) Dosedependent effects of endotoxin on human sleep. Am J Physiol Regul Integr Comp Physiol 278(4):R947-R955

97. Nagele RG, Wegiel J, Venkataraman V, Imaki H, Wang KC, Wegiel J (2004) Contribution of glial cells to the development of amyloid plaques in Alzheimer's disease. Neurobiol Aging 25(5): 663-674

98. Neumann H (2001) Control of glial immune function by neurons. Glia 36(2):191-199

99. Nguyen DN, Spapen H, Su F et al (2006) Elevated serum levels of S-100beta protein and neuron-specific enolase are associated with brain injury in patients with severe sepsis and septic shock. Crit Care Med 34(7):1967-1974

100. Nishioku T, Dohgu S, Takata F et al (2009) Detachment of brain pericytes from the basal lamina is involved in disruption of the blood-brain barrier caused by lipopolysaccharide-induced sepsis in mice. Cell Mol Neurobiol 29(3):309-316

101. Noble F, Rubira E, Boulanouar M et al (2007) Acute systemic inflammation induces central mitochondrial damage and mnesic deficit in adult Swiss mice. Neurosci Lett 7;424(2): $106-110$
102. O'Keeffe ST, Ní Chonchubhair A (1994) Postoperative delirium in the elderly. Br J Anaesth 73(5):673-687

103. Olson JK, Miller SD (2004) Microglia initiate central nervous system innate and adaptive immune responses through multiple TLRs. J Immunol 173(6):3916-3924

104. Oztaş B, Akgül S, Arslan FB (2004) Influence of surgical pain stress on the blood-brain barrier permeability in rats. Life Sci 74(16): 1973-1979

105. Pugh CR, Kumagawa K, Fleshner M, Watkins LR, Maier SF, Rudy JW (1998) Selective effects of peripheral lipopolysaccharide administration on contextual and auditory-cue fear conditioning. Brain Behav Immun 12(3):212-229

106. Qiao X, Cummins DJ, Paul SM (2001) Neuroinflammationinduced acceleration of amyloid deposition in the APPV717F transgenic mouse. Eur J Neurosci 14(3):474-482

107. Qin L, Wu X, Block ML et al (2007) Systemic LPS causes chronic neuroinflammation and progressive neurodegeneration. Glia 55(5):453-462

108. Qu T, Uz T, Manev H (2000) Inflammatory 5-LOX mRNA and protein are increased in brain of aging rats. Neurobiol Aging 21(5):647-652

109. Rachal Pugh C, Fleshner M, Watkins LR, Maier SF, Rudy JW (2001) The immune system and memory consolidation: a role for the cytokine IL-1beta. Neurosci Biobehav Rev 25(1):29-41

110. Reichenberg A, Yirmiya R, Schuld A et al (2001) Cytokineassociated emotional and cognitive disturbances in humans. Arch Gen Psychiatry 58(5):445-452

111. Richwine AF, Parkin AO, Buchanan JB et al (2008) Architectural changes to CA1 pyramidal neurons in adult and aged mice after peripheral immune stimulation. Psychoneuroendocrinology 33(10):1369-1377

112. Richwine AF, Sparkman NL, Dilger RN, Buchanan JB, Johnson RW (2009) Cognitive deficits in interleukin-10-deficient mice after peripheral injection of lipopolysaccharide. Brain Behav Immun 23(6):794-802

113. Rosczyk HA, Sparkman NL, Johnson RW (2008) Neuroinflammation and cognitive function in aged mice following minor surgery. Exp Gerontol 43(9):840-846

114. Sakamoto K, Arakawa H, Mita S et al (1994) Elevation of circulating interleukin 6 after surgery: factors influencing the serum level. Cytokine 6(2):181-186

115. Sampson EL, Blanchard MR, Jones L, Tookman A, King M (2009) Dementia in the acute hospital: prospective cohort study of prevalence and mortality. Br J Psychiatry 195(1):61-66

116. Sastre M, Walter J, Gentleman SM (2008) Interactions between APP secretases and inflammatory mediators. J Neuroinflamm 5:25

117. Schram MT, Euser SM, de Craen AJ et al (2007) Systemic markers of inflammation and cognitive decline in old age. J Am Geriatr Soc 55(5):708-716

118. Semmler A, Okulla T, Sastre M, Dumitrescu-Ozimek L, Heneka M (2005) Systemic inflammation induces apoptosis with variable vulnerability of different brain regions. J Chem Neuroanat 30:144-157

119. Sharshar T, Carlier R, Bernard F et al (2007) Brain lesions in septic shock: a magnetic resonance imaging study. Intensive Care Med 33(5):798-806

120. Sharshar T, Gray F, Lorin de la Grandmaison G et al (2003) Apoptosis of neurons in cardiovascular autonomic centres triggered by inducible nitric oxide synthase after death from septic shock. Lancet 362(9398):1799-1805

121. Shawcross DL, Shabbir SS, Taylor NJ, Hughes RD (2009) Ammonia and the neutrophil in the pathogenesis of hepatic encephalopathy in cirrhosis. Hepatology. doi:10.1002/hep.23367

122. Sheng JG, Bora SH, Xu G, Borchelt DR, Price DL, Koliatsos VE (2003) Lipopolysaccharide-induced-neuroinflammation increases 
intracellular accumulation of amyloid precursor protein and amyloid beta peptide in APPswe transgenic mice. Neurobiol Dis 14(1):133-145

123. Shimaoka M, Park EJ (2008) Advances in understanding sepsis. Eur J Anaesthesiol Suppl 42:146-153

124. Siami S, Annane D, Sharshar T (2008) The encephalopathy in sepsis. Crit Care Clin 24(1):67-82, viii

125. Siddiqi N, House AO, Holmes JD (2006) Occurrence and outcome of delirium in medical in-patients: a systematic literature review. Age Ageing 35(4):350-364

126. Sparkman NL, Buchanan JB, Heyen JR, Chen J, Beverly JL, Johnson RW (2006) Interleukin-6 facilitates lipopolysaccharideinduced disruption in working memory and expression of other proinflammatory cytokines in hippocampal neuronal cell layers. J Neurosci 26(42):10709-10716

127. Stagno D, Gibson C, Breitbart W (2004) The delirium subtypes: a review of prevalence, phenomenology, pathophysiology, and treatment response. Palliat Support Care 2(2):171-179

128. Stinghen AE, Gonçalves SM, Martines EG et al (2009) Increased plasma and endothelial cell expression of chemokines and adhesion molecules in chronic kidney disease. Nephron Clin Pract 111(2):c117-c126

129. Sun Y, Tawara I, Toubai T, Reddy P (2007) Pathophysiology of acute graft-versus-host disease: recent advances. Transl Res 150(4):197-214

130. Tanaka S, Ide M, Shibutani T et al (2006) Lipopolysaccharideinduced microglial activation induces learning and memory deficits without neuronal cell death in rats. J Neurosci Res 83(4):557-566

131. Thompson WL, Karpus WJ, Van Eldik LJ (2008) MCP-1-deficient mice show reduced neuroinflammatory responses and increased peripheral inflammatory responses to peripheral endotoxin insult. J Neuroinflamm 5:35

132. Tizard I (2008) Sickness behavior, its mechanisms, significance. Anim Health Res Rev 9(1):87-99

133. Trzepacz PT (2000) Is there a final common neural pathway in delirium? Focus on acetylcholine and dopamine. Semin Clin Neuropsychiatry 5(2):132-148

134. Trzepacz PT, Mulsant BH, Dew MA, Pasternak R, Sweet RA, Zubenko GS (1998) Is delirium different when it occurs in dementia? A study using the delirium rating scale. J Neuropsychiatry Clin Neurosci 10(2):199-204

135. Uchikado H, Akiyama H, Kondo $\mathrm{H}$ et al (2004) Activation of vascular endothelial cells and perivascular cells by systemic inflammation-an immunohistochemical study of postmortem human brain tissues. Acta Neuropathol 107(4):341-351
136. Uylings HB, de Brabander JM (2002) Neuronal changes in normal human aging and Alzheimer's disease. Brain Cogn 49(3):268-276

137. van der Cammen TJ, Tiemeier H, Engelhart MJ, Fekkes D (2006) Abnormal neurotransmitter metabolite levels in Alzheimer patients with a delirium. Int J Geriatr Psychiatry 21(9): 838-843

138. van der Mast RC, Roest FH (1996) Delirium after cardiac surgery: a critical review. J Psychosom Res 41(1):13-30

139. van Munster BC, Korevaar JC, Korse CM, Bonfrer JM, Zwinderman AH, de Rooij SE (2010) Serum S100B in elderly patients with and without delirium. Int $\mathrm{J}$ Geriatr Psychiatry 25(3):234-239

140. van Munster BC, Korevaar JC, Zwinderman AH, Levi M, Wiersinga WJ, De Rooij SE (2008) Time-course of cytokines during delirium in elderly patients with hip fractures. J Am Geriatr Soc 56(9): 1704-1709

141. Volterra A, Meldolesi J (2005) Astrocytes, from brain glue to communication elements: the revolution continues. Nat Rev Neurosci 6(8):626-640

142. von Bernhardi R, Ramírez G, Toro R, Eugenín J (2007) Proinflammatory conditions promote neuronal damage mediated by amyloid precursor protein and decrease its phagocytosis and degradation by microglial cells in culture. Neurobiol Dis 26(1): $153-164$

143. Wan Y, Xu J, Ma D, Zeng Y, Cibelli M, Maze M (2007) Postoperative impairment of cognitive function in rats: a possible role for cytokine-mediated inflammation in the hippocampus. Anesthesiology 106(3):436-443

144. Weichhart T, Haidinger M, Hörl WH, Säemann MD (2008) Current concepts of molecular defence mechanisms operative during urinary tract infection. Eur J Clin Invest 38(Suppl 2): 29-38

145. Williams-Russo P, Urquhart BL, Sharrock NE, Charlson ME (1992) Post-operative delirium: predictors and prognosis in elderly orthopedic patients. J Am Geriatr Soc 40(8):759-767

146. World Health Organization (1992) The ICD-10 classification of mental and behavioural disorders: clinical descriptions and diagnostic guidelines. World Health Organization, Geneva

147. Yang FM, Marcantonio ER, Inouye SK et al (2009) Phenomenological subtypes of delirium in older persons: patterns, prevalence, and prognosis. Psychosomatics 50(3):248-254

148. Yankner BA, Lu T, Loerch P (2008) The aging brain. Annu Rev Pathol 3:41-66

149. Young GB, Pigott SE (1999) Neurobiological basis of consciousness. Arch Neurol 56(2):153-157 